Marija Mihaljević Marina Matković Zorislav Horvat
UDK: 902.2(497.541Ivandol)

DOI: https://dx.doi.org/10.21857/90836cw31y

Prethodno priopćenje

Rukopis prihvaćen za tisak: 13. 6. 2018.

\title{
ARHEOLOŠKA ISTRAŽIVANJA LOKALITETA NJIVE-IVANDOL - KAO PRILOG POZNAVANJU SREDNJOVJEKOVLJA POŽEŠKE KOTLINE
}

\begin{abstract}
Sažetak
U radu se predstavljaju rezultati istraživanja rotunde građene kamenim klesancima pronađene na srednjovjekovnom lokalitetu Njive (Njivice) - Ivandol u Požeškoj županiji, koja se datira u razdoblje romanike i gotike. Pretpostavlja se da se rotunda nalazi na nekadašnjem srednjovjekovnom posjedu Odolja, koji je pripadao unuku bana Borića, a u 13. stoljeću u vlasništvu je templara. U radu se pregledno navode i ostale rotunde u Hrvatskoj te neki primjeri iz Europe kako bi se usporedila učestalost gradnje takvog tipa sakralne građevine na prostoru Hrvatske u razdoblju razvijenog i kasnog srednjeg vijeka.
\end{abstract}

Ključne riječi: rotunda; srednji vijek; klesanci; ban Borić; Odolja.

\section{Uvod}

Požeška kotlina svojim geografskim obilježjima oduvijek je pružala iznimno dobre uvjete za život, pa tako danas poznajemo brojne lokalitete iz vremena prapovijesti, antike i srednjeg vijeka sve do današnjeg vremena. Kada govorimo o srednjovjekovlju Požeške kotline, rani srednji vijek još nam je uvijek vrlo slabo poznat u kontekstu arheoloških nalaza, koji su vrlo oskudni za to razdoblje te se tek u razvijenom i kasnom srednjem vijeku tragom pisanih izvora dobivaju spoznaje o velikom broju naselja vezanih uz plemićke i crkvene posjede, a time i postojanje brojnih crkava, kapelica i utvrda po obroncima Požeške kotline. Brojna naselja očuvala su se sve do današnjeg vremena, neka na svojim srednjovjekovnim položajima, neka u bližoj okolici, a lokalitet Njive - Ivandol upravo je jedan od lokaliteta koji svjedoči o postojanju srednjovjekovnog naselja u njegovoj neposrednoj blizini, prema svemu sudeći posjedu Odolja. Poznati su nam brojni primjeri crkava koje potječu iz srednjega vijeka te su očuvale svoju funkciju do današnjih vremena, iako je velika većina njih uništena, a samo ih je mali broj poznat tek $u$ arheološkom sloju. Jedna je od takvih i ivandolska rotunda, čija namjena nakon višegodišnjih arheoloških istraživanja još 
uvijek nije u potpunosti dokazana. U ovom se radu donose rezultati istraživanja te rotunde koja pokazuje da se radi o iznimnom objektu koji je nezaobilazan primjer za proučavanje sakralne arhitekture srednjovjekovlja Požeške kotline, pa i Slavonije.

\section{Geografski položaj}

Arheološki lokalitet Njive - Ivandol nalazi se u Požeško-slavonskoj županiji oko 14 km zapadno od Požege, u blizini županijske ceste koja povezuje Požegu s Novom Gradiškom. Najbliža su naseljena mjesta Ivandol i Busnovi (lokalitet Njive od sela Ivandol udaljen je oko 1,5 km južno, a od sela Busnovi oko 2 km jugozapadno). Lokalitet je smješten na sjevernim padinama Požeške gore, koje su pokrivene bjelogoričnom i mješovitom šumom. Veća uzvišenja u blizini su Smiljevača (486 m n. v.) oko 500 m jugozapadno od lokaliteta i najviši vrh Požeške gore Kapavac (618 m n. v.) oko 3 km jugoistočno od lokaliteta. U blizini su i vodotoci Bojana, Kosovac i Zagulin. Kršćansko groblje obližnjih naselja ${ }^{1}$ nalazi se u neposrednoj blizini lokaliteta, oko 10 m jugozapadno, na 356 m n. v. Arheološki lokalitet smješten je na izduženom grebenu sa središnjim uzvišenjem, orijentiranim u smjeru SZ - JI, azimut $315^{\circ} \mathrm{SZ}$ (sl. 1, 2).

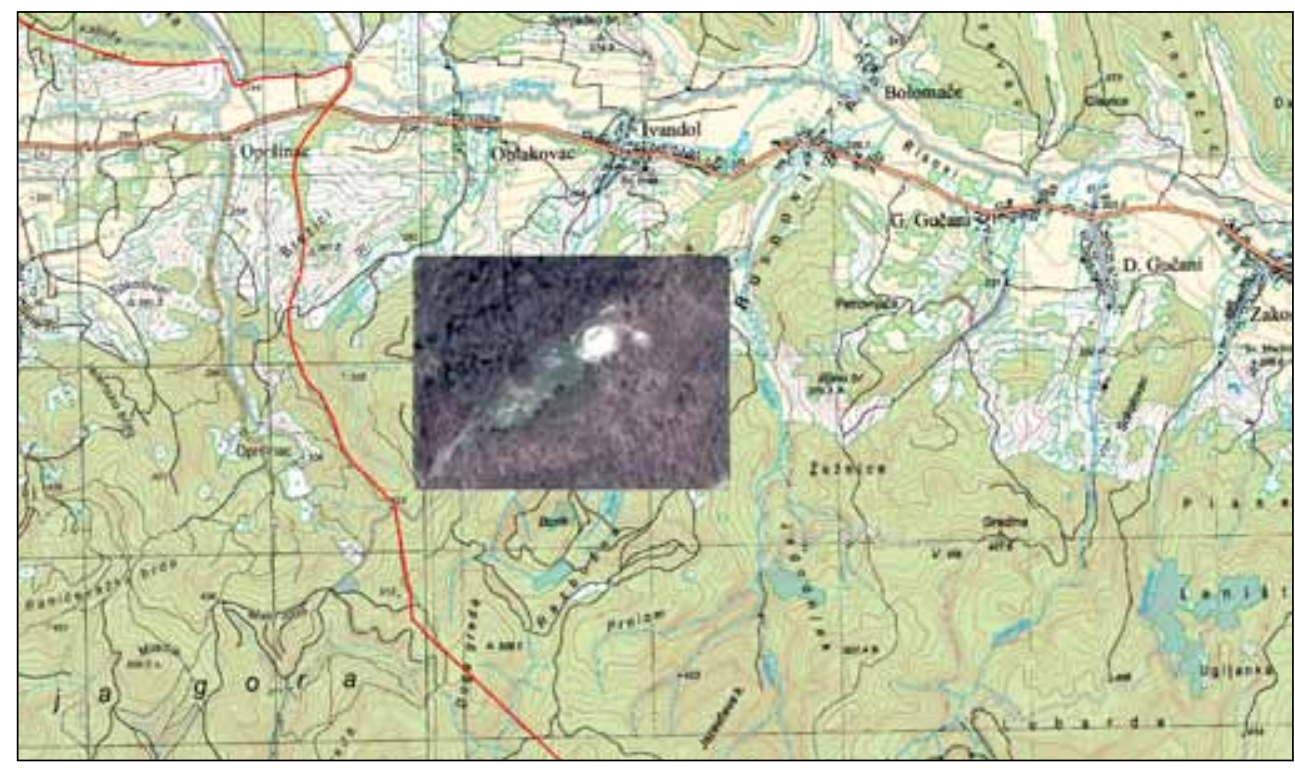

Slika 1. Položaj nalazišta na karti $1: 25000$ (detalj crkve s grobljem)

1 Groblje katoličkog i pravoslavnog stanovništva naselja Busnovi i Ivandol; danas postoji novo mjesno groblje u lvandolu, dok se na ovom groblju obavlja tek poneki ukop u već postojeća grobna mjesta. 


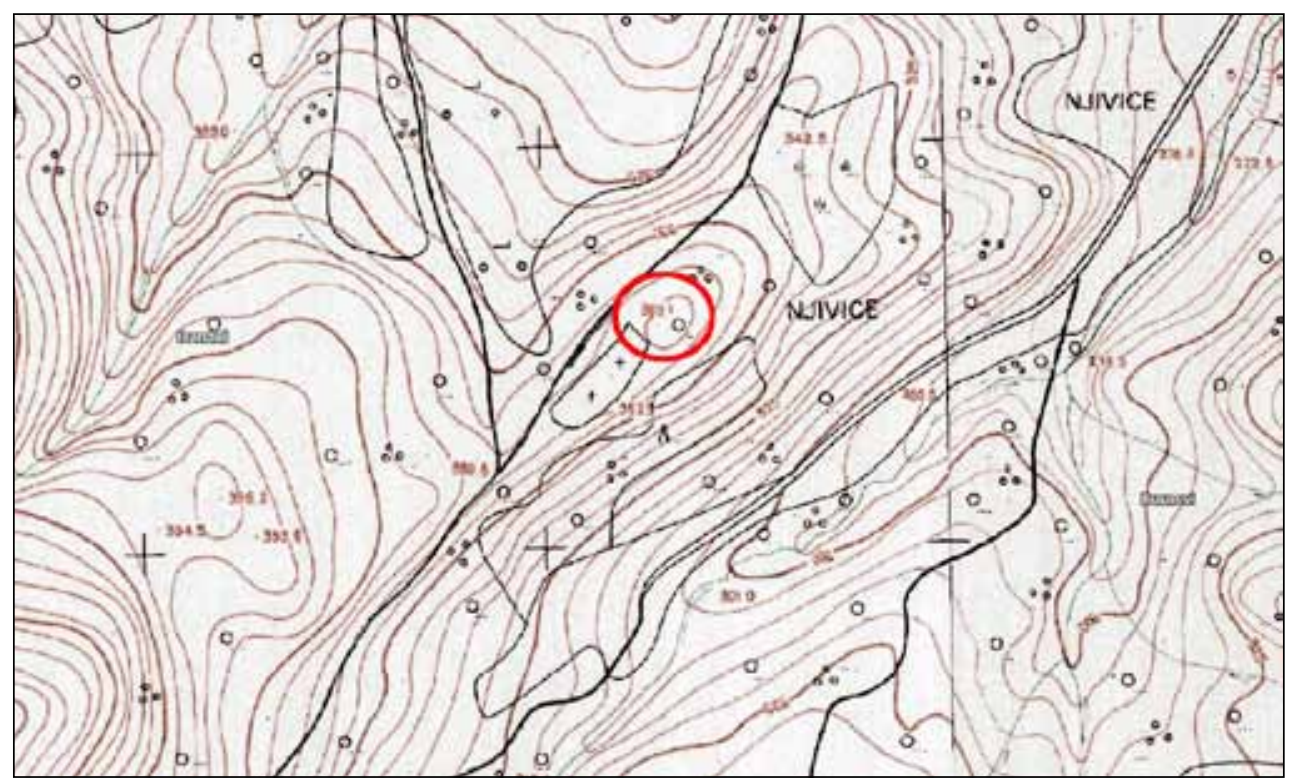

Slika 2. Položaj nalazišta na karti $1: 5000$ (HOK)

\section{Povijesni podaci}

U uvodnom dijelu spomenut je srednjovjekovni posjed Odolja, za koji još uvijek ne postoji točna ubikacija. Većina autora koja se bavila pisanim povijesnim izvorima o njemu slaže se da bi Odolju trebalo tražiti u Požeškoj županiji, iako je Lelja Dobronić smatrala da je taj posjed zapravo Gora, jer se tamo nalazi crkva istog titulara - sv. Marije (Dobronić, 1984/34). Gjuro Szabó smatrao je da se posjed Odolja (nazvao ga Odohila/Odola) nalazio između Bijelog brijega i Požege, istočno od templarskih posjeda oko Psunja (Szabó, 1908/1909), dok Josip Buturac iznosi mišljenje da se taj posjed nalazio jugoistočno od Rudine, na obroncima Psunja ili Požeške gore. Činjenicu da se posjed spominje $\mathrm{u}$ istoj ispravi s Ljesnicom i Racessom, kao i to da je Odolja bio nasljedni posjed Borićeva potomka Odole, a svi do sada poznati nasljedni posjedi roda Borića bana smješteni su u Požeškoj županiji (pri tome ostavlja mogućnost da je posjed Odolja darovan upravo zato što je bio udaljen od drugih posjeda, čime bi tvrdnja Lelje Dobronić mogla biti valjana) (Karbić, 2005.). U pisanim povijesnim izvorima posjed se spominje već od 13. stoljeća kroz razne isprave, a često se spominje zajedno s posjedom Orljavac (Oryawa/Oryawawar), kao dio njegove gospoštije. Posjed Odolja/Odola prvi se put spominje u povelji iz 1210. godine kojom kralj Andrija II. potvrđuje templarskom redu više posjeda, između kojih i Odolin posjed. Tom prilikom navodi se da Odola, unuk bana Borića, daruje templarskom redu ze- 
mlje koje čine obrađeno i neobrađeno zemljište, šume, livade, vinogradi i ribnjaci, a navodi se i crkva sv. Marije osnovana u središtu posjeda (... cum ecclesia sancte Maria in medio fundata...) (Smičiklas, 1905). U srednjem vijeku taj je posjed graničio s posjedom Koprivna (današnja Koprivna u Požeško-slavonskoj županiji) (Heller, 1975), čije su dijelove u 14. stoljeću posjedovali Odolini unuci (1349. kao posjednici dijela posjeda Koprivna spominju se Nikola i Juraj, Odolini unuci) (Karbić, 2005), a pripadao je Požeškoj županiji. Odolja/Odola spominje se i 1388. godine, kada Bosansko-đakovački kaptol obavještava kralja Žigmunda da je u posjed Odolya uveo Elizabetu, ženu Dionizija, i Klaru, ženu Nikole (Buturac, 2004). Crkva sv. Marije ponovno se spominje 1422. godine, kao ecclesia B. V. Marie de Odolya (Heller, 1975), a dolaskom Osmanlija na te prostore posjed je napušten te je pripao požeškim spahijama (Marković, 2002). Posljednji spomen Odolje nalazimo u radu Nenada Moačanina temeljenom na turskim općim poreznim popisima za Požeški sandžak, gdje stoji „Ivan Dol, srednjovjekovna Odolja” (Moačanin, 2003). Prateći dalje spomen Ivandola, u popisu vojvodstva Brestovac iz 1698. godine navodi se da u selu Ivandol nema ostataka crkve ili dvorca, da je naseljeno vojnicima katoličke vjere koji ne znaju za kršćanskog zemljišnog gospodara, a pripadaju spahiji u Požegi (Sršan, 2000).

Danas se Ivandol nalazi uz državnu cestu D51, ali poznato je da se Ivandol nekada nalazio južnije nego što je danas, uvučen među obronke Požeške gore, kao što je bio slučaj i s mnogim drugim naseljima. Tako na prvim topografskim kartama Habsburške Monarhije, nastalim u vremenu 1763. - 1787. godine, vidimo položaj naselja Ivandol na obroncima Požeške gore, bez označene crkve ili groblja u neposrednoj blizini. Na topografskim kartama nastalim prilikom treće izmjere, u vremenu između 1869. i 1887. vidimo da je naselje još uvijek smješteno na obroncima, ali ovoga je puta označeno groblje ${ }^{2}$ smješteno upravo na položaju današnjeg lokaliteta Njive - Ivandol.

\section{Arheološka istraživanja}

Prva probna arheološka istraživanja lokaliteta Njive - Ivandol proveo je 1999. godine Gradski muzej Požega pod vodstvom arheologinje i tadašnje ravnateljice muzeja Dubravke Sokač Štimac. Prilikom istraživanja otkriven je na južnom dijelu povišenog platoa polukružni zid $u$ duljini $7 \mathrm{~m}$, debljine $0,90 \mathrm{~m}$ i visine do $1 \mathrm{~m}$ (sl. 3). Osim tog zida, na istočnoj strani platoa pronađena su tri kostuma ukopa, orijentirana jug - sjever (s glavama na jugu) te dosta dislociranih kostiju. Od pokretnih nalaza pronađeno je dosta ulomaka srednjovjekovne keramike, metalnih uporabnih predmeta (čavli, klinovi, kopče, karike itd.) te jedna metalna aplika s prikazom lji-

2 Današnje staro mjesno groblje o kojemu je bilo riječi u opisu geografskog položaja lokaliteta. 


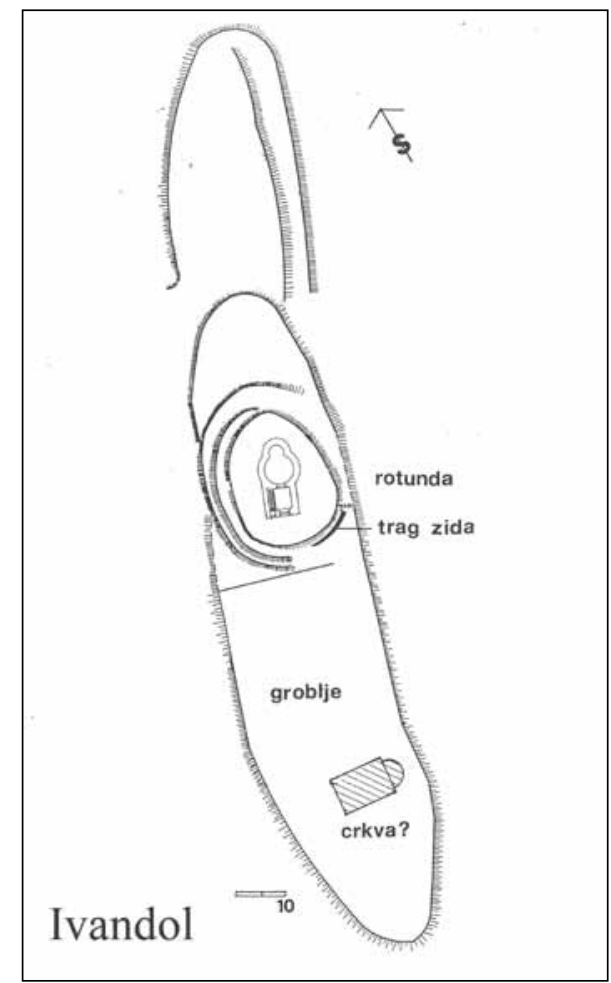

Slika 3. Situacija groblja i rotunde - položaj crkve u groblju tek je pretpostavljen kao mogućnost

ljana. ${ }^{3}$ Probnim istraživanjima potvrđeno je da lokalitet pripada razdoblju srednjega vijeka, ali se daljnja istraživanja lokaliteta nisu nastavila te su rezultati probnog istraživanja ostali neobjavljeni. Arheološkom istraživanju tog lokaliteta ponovno se pristupilo 2013. godine, kada je obavljen terenski pregled lokaliteta i priprema za arheološko istraživanje, ovoga puta u suradnji Konzervatorskog odjela u Požegi i Gradskog muzeja Nova Gradiška. Pod vodstvom više kustosice i ravnateljice dr. sc. Marije Mihaljević provode se sustavna arheološka istraživanja od kolovoza 2013. godine (sl. 3) u kojima su otkriveni ostaci srednjovjekovne sakralne građevine - rotunde s polukružnom apsidom i pravokutnom prostorijom (sl. 4-6), brojni kosturni ukopi gusto raspoređeni oko rotunde, značajan broj pokretnih nalaza te ulomci arhitektonske plastike (sl. 7) koji po svojim stilskim karakteristikama mogu

3 Rezultati probnog istraživanja provedenog 1999. godine nisu objavljeni, a podatke o nalazima ustupila nam je prof. Dubravka Šokač-Štimac, kojoj ovim putem zahvaljujemo. 


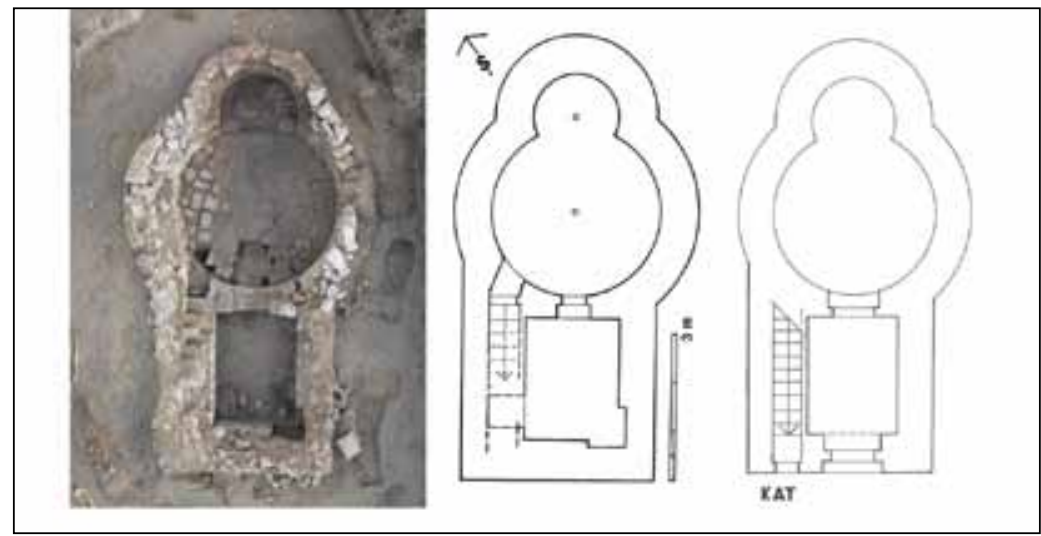

Slika 4. Tlocrti rotunde na lokalitetu Njive - Ivandol, zračna snimka rotunde (foto: M. Hucaljuk), donja etaža rotunde (crtež: Z. Horvat), gornja etaža rotunde (pokušaj djelomične rekonstrukcije, isti autor)

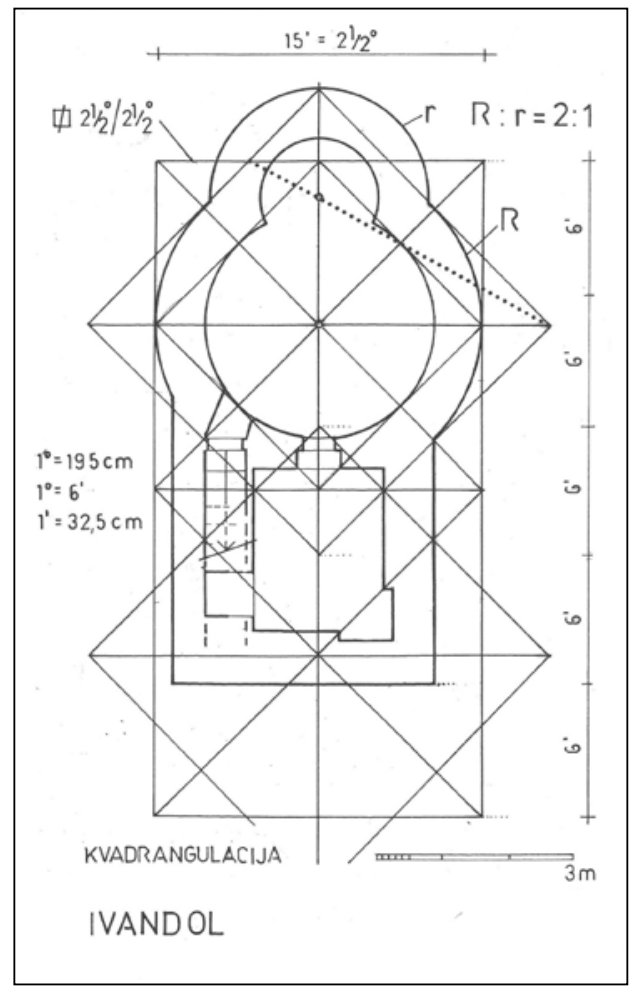

Slika 5. Lokalitet Njive - Ivandol, pokušaj kvadrangulacije rotunde (Z. Horvat) 


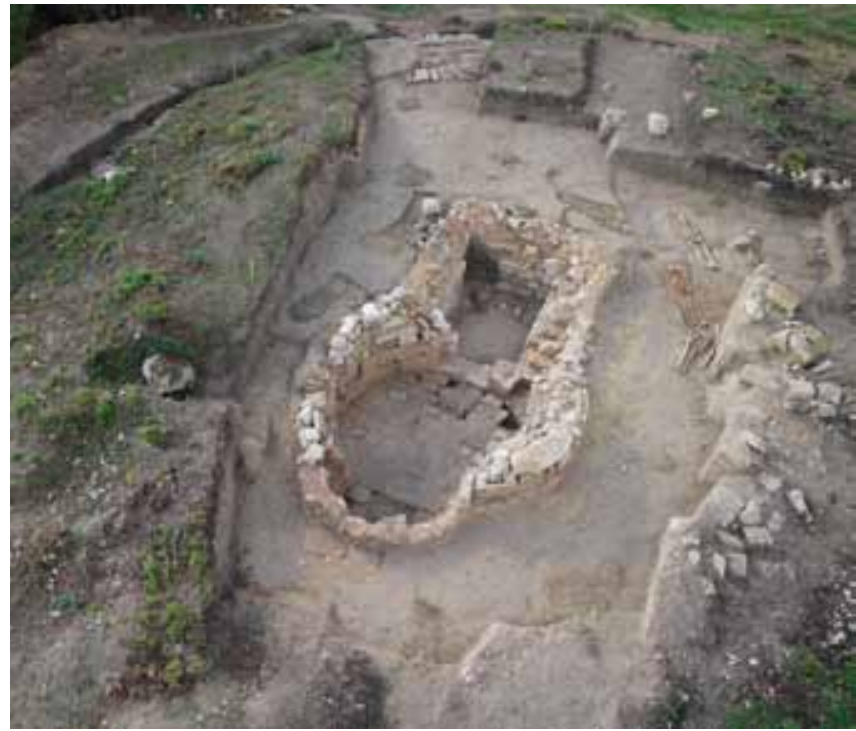

Slika 6. Lokalitet Njive - Ivandol, zračna snimka pogleda na rotundu i njezinu apsidu (apsida i pravokutna prostorija) (foto: M. Huculjak)

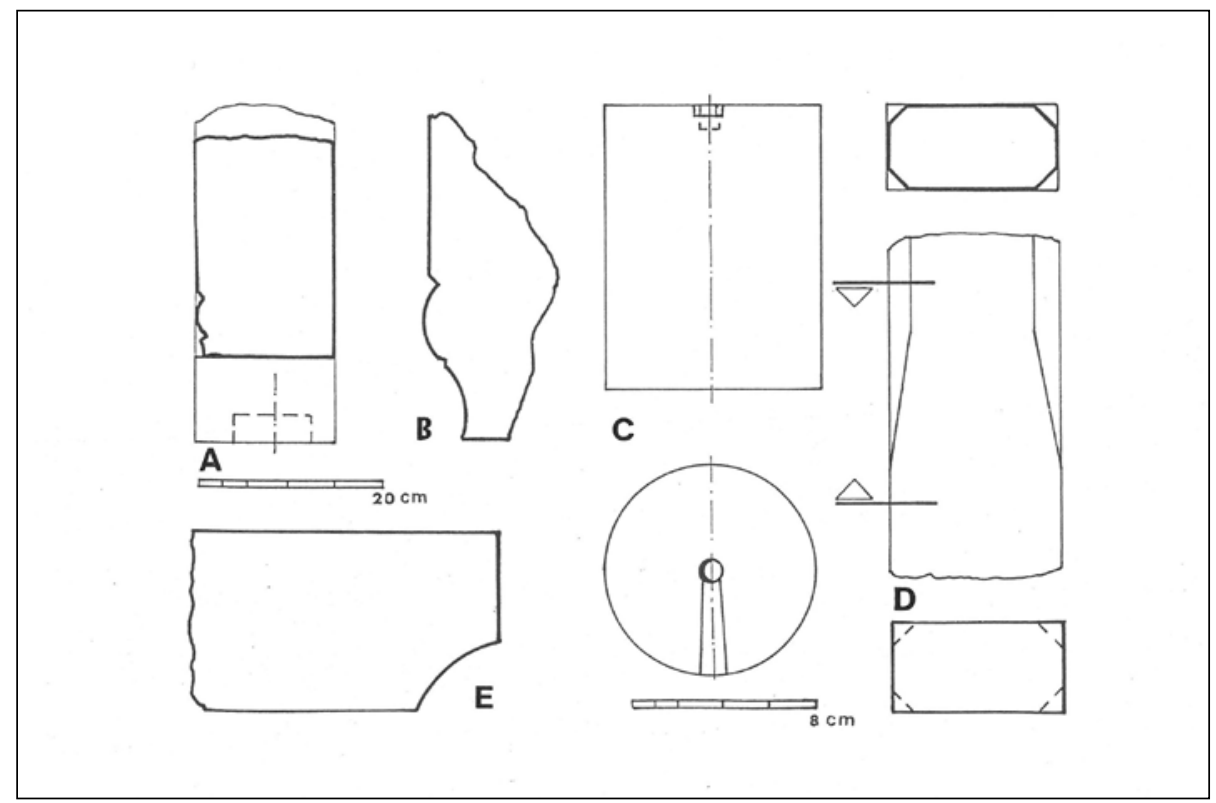

Slika 7. Lokalitet Njive - Ivandol, ulomci arhitektonske plastike (crtež: Z. Horvat) 
pripadati razdoblju romanike i gotike. Arheološkim istraživanjima 2013. - 2018. godine istraženo je 130 kosturnih ukopa, koji su gusto raspoređeni oko rotunde, $\mathrm{s}$ tendencijom orijentacije prema apsidi rotunde. Orijentacija rotunde jest SI - JZ jer prati prirodan smjer pružanja grebena na kojem se nalazi, no jasno se uočava tendencija za smještajem apside na istoku, što je gotovo uvijek pravilo kada se radi o srednjovjekovnim sakralnim objektima. Na JZ kosturni ukopi polagani su u obične zemljane rake, a ostaci drvenih lijesova pronađeni su u manjem broju grobova. Prisutan je samo jedan ukop u grobnici orijentiran Z - I s glavom pokojnika prema zapadu. Grobnica je napravljena od sekundarno iskorištenih ulomaka arhitektonske plastike.

Grobovi su većinom bez pokretnih nalaza, osim nekoliko grobova u kojima su uz pokojnika pronađeni komadi nakita ili dijelovi nošnje. Ukopi su obavljani u više horizonata, na različitim dubinama, stoga se događalo da mlađi ukopi unište starije. Istraženi grobovi prema svojim karakteristikama datirani su u razdoblja kasnog srednjeg i novog vijeka.

Među pokretnim arheološkim nalazima najbrojniju skupinu čine ulomci keramičkog posuđa, zatim slijede kovani željezni čavli, a posebno su zanimljivi nalazi željeznih vrhova strelica različitih tipova pronađenih većinom na jugoistočnom dijelu lokaliteta. Od posebnih nalaza najbrojniji je srednjovjekovni kovani novac kovan većinom za vrijeme vladavine Matijaša Korvina (1482. - 1486.) i Vladislava II. Jagelovića (1490. - 1516) (Unger, 1997; Rethy, 1958), zatim slijede dijelovi nošnji i nakit (prstenje, aplike, kopčice...), a pronađena je i značajna količina ulomaka arhitektonske plastike koja se po svojim obilježjima datira u razdoblja romanike i gotike. Preliminarnim analizama sav pokretni arheološki materijal može se okvirno datirati u razdoblja kasnog srednjeg i novog vijeka, između 13. i 16. stoljeća.

\section{Rotunda}

Građevina otkrivena na ovom lokalitetu tlocrtom je rotunda s polukružnom apsidom na sjeveroistoku i pravokutnom prostorijom sa stubištem na jugozapadu $u$ istoj osi) (sl. 4). Građevina prati prirodni smjer pružanja grebena na kojem se nalazi, a očita je tendencija graditelja da je pozicionira onako kako je to bilo uobičajeno $u$ srednjem vijeku - ulaz na zapadu, svetište na istoku. Unutrašnji promjer rotunde iznosi $340 \mathrm{~cm}$, dok je vanjski promjer $510 \mathrm{~cm}$, iz čega proizlazi da je debljina zidova rotunde $98 \mathrm{~cm}$, odnosno 3 stope $=3^{\prime}$, veličine $32,5 \mathrm{~cm}$. Na SI strani rotunde nalazi se polukružna apsida, a na JZ dijelu rotunde pravokutna prostorija dimenzija 4,0/3,7 $-4,3 \mathrm{~m}$, u čiji je zapadni zid ugrađeno stubište (širina $63 \mathrm{~cm}$ ) koje vodi u rotundu (Mihaljević, Horvat, Matković, 2015). U južnom kutu prostorije nalaze se dvije spojene niše čija namjena nije sasvim jasna, ali pretpostavlja se da bi jedna od njih mogla služiti za ozračivanje prostora. 
Cijela ta građevina vrlo je kvalitetno izgrađena od kamenih klesanaca (sl. 8) kakve još nalazimo na obližnjoj Rudini, a pri njezinoj izgradnji korištene su tri vrste kamena: krupnozrnati pješčenjak, šupljikavi kamen koji podsjeća na srednjovjekovno ziđe zagrebačke katedrale (litotamnijski vapnenac), te sedra, koja se vrlo često koristila za izvedbu svodova zbog svoje lakoće i zadovoljavajuće čvrstoće (Mihaljević, Horvat, Matković, 2015). Sedra je najvećim dijelom pronađena u zasipu unutrašnjosti građevine, $\mathrm{i}$ to $\mathrm{u}$ brodu i apsidi rotunde, što ukazuje na to $\mathrm{d}$ a je taj prostor vjerojatno bio svođen. Na sjevernoj strani rotunde očuvano je najviše zida, tako da s vanjske strane imamo očuvane i fasadne klesance, vrlo kvalitetno izvedene (sl. 9). Unutrašnji zidovi rotunde nisu ujednačeni u gradnji i očituje se jasna razlika između južne i sjeverne strane rotunde. Sjeverna strana sadrži i neke sekundarno iskorištene arhitektonske ulomke, npr. profilirani klesanac ugrađen na sjevernoj strani, dok su klesanci u apsidi i na južnoj strani pravilnije složeni i ujednačenih dimenzija. I na višim razinama vide se odstupanja. Sjeverni zid građen je od kamena različitih dimenzija u kombinaciji s klesancima, pretpostavljamo kako je sjeverna strana bila rušena i obnavljana, ali pravilnost $u$ gradnji rotunde jasno se očituje $u$ najnižem redu klesanaca koji se tek nekoliko centimetara izdiže iznad podnice. Tlocrt pokazuje savršenu kružnicu s dodatkom polukružne apside te ujednačenost i pravilnost u

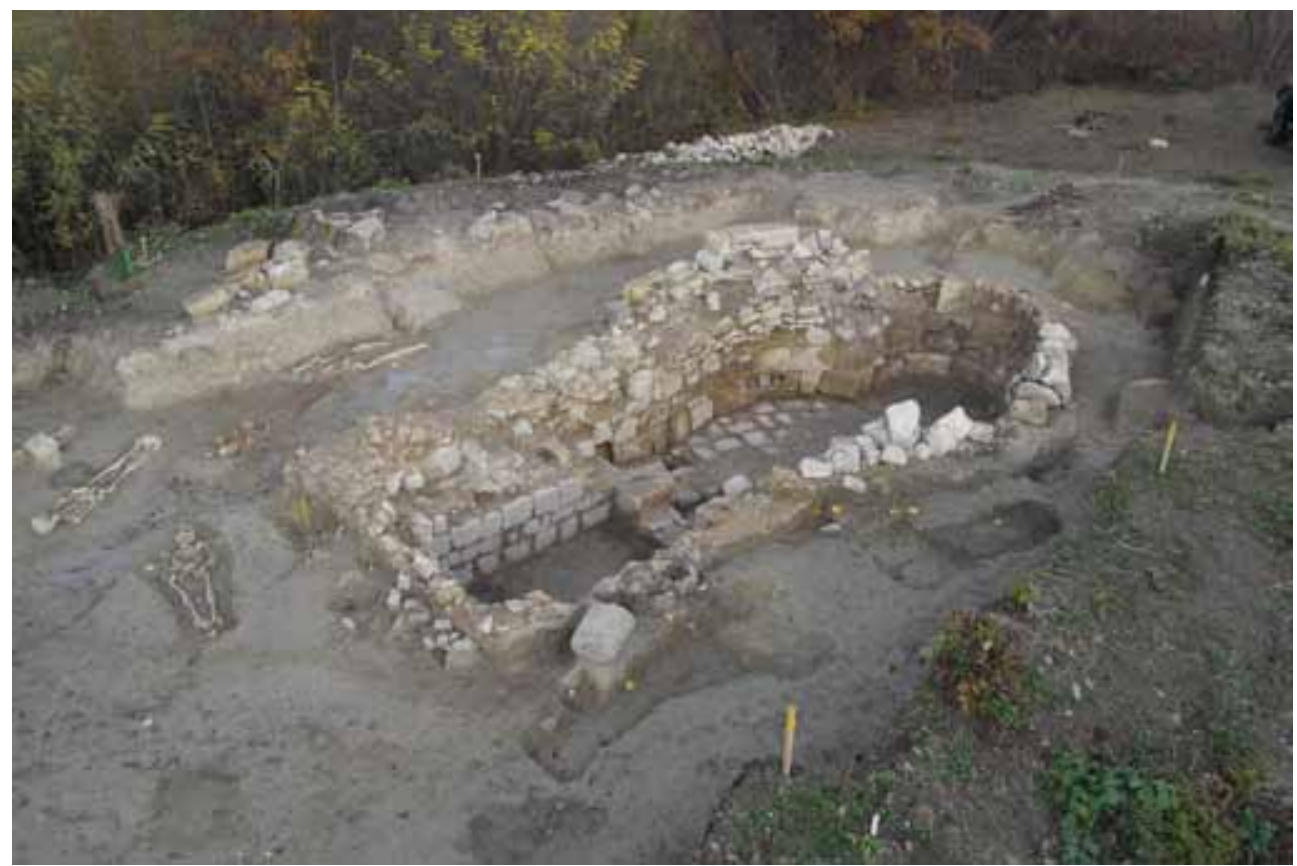

Slika 8. Lokalitet Njive - Ivandol, pogled na rotondu, pogled s juga (foto: M. Huculjak) 


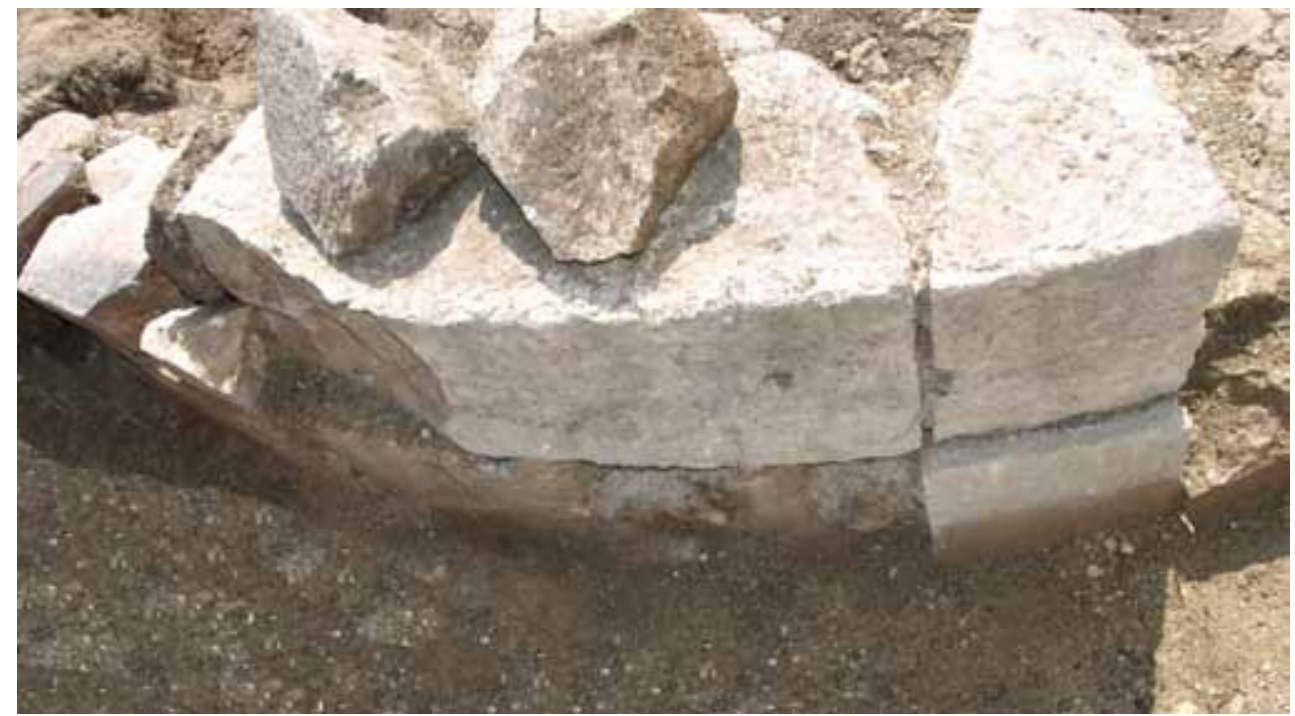

Slika 9. Lokalitet Njive - Ivandol, detalj klesanca (foto: M. Mihaljević)

dimenzijama klesanaca. Nepravilnosti u zidanju najizraženije su na sjevernoj strani rotunde i ukazuju na naknadne intervencije na građevini (tj. popravak zidova nakon urušavanja dijela građevine) (sl. 10). Zidovi prostorije na JZ građeni su kamenim klesancima nešto manjih dimenzija u usporedbi s klesancima iz rotunde, a zidovi su vrlo dobro očuvani. Na spoju rotunde i pravokutne prostorije nalazi se otvor za vrata, širine oko $50 \mathrm{~cm}$, koja su se otvarala u pravokutnu prostoriju. Stubište je također kvalitetno izvedeno klesancima, iako nije najbolje očuvano, samo je najniža stuba cjelovita (Mihaljević, Horvat, Matković, 2014). Na unutrašnjim zidovima građevine ponegdje se vide ostaci vapnene žbuke, a mnogo ulomaka žbuke pronađeno je i tijekom istraživanja unutrašnjosti. Posebnost te građevine jest $u$ tome što je očuvana $u$ dijelu koji je funkcionirao kao podzemna etaža (sl. 11), čemu svjedoče stube kojima se silazi u rotundu, ali i fasadni klesanci na sjevernom zidu rotunde koji ukazuju na hodnu razinu tla $u$ vrijeme kada je građena. Može se pretpostaviti da je postojala $\mathrm{i}$ nadzemna etaža, no kako je ona točno izgledala, može se samo nagađati.

Također, velika je zanimljivost podnica od kamenih ploča manjih i relativno ujednačenih dimenzija koja je očuvana gotovo u cijelosti (sl. 12). U apsidi se koristila kombinacija klesanog kamena i rimske opeke za popločenje, što je ostalo samo djelomično očuvano, a u pravokutnoj prostoriji pronađeni su u kutovima tragovi kamenog popločenja. 


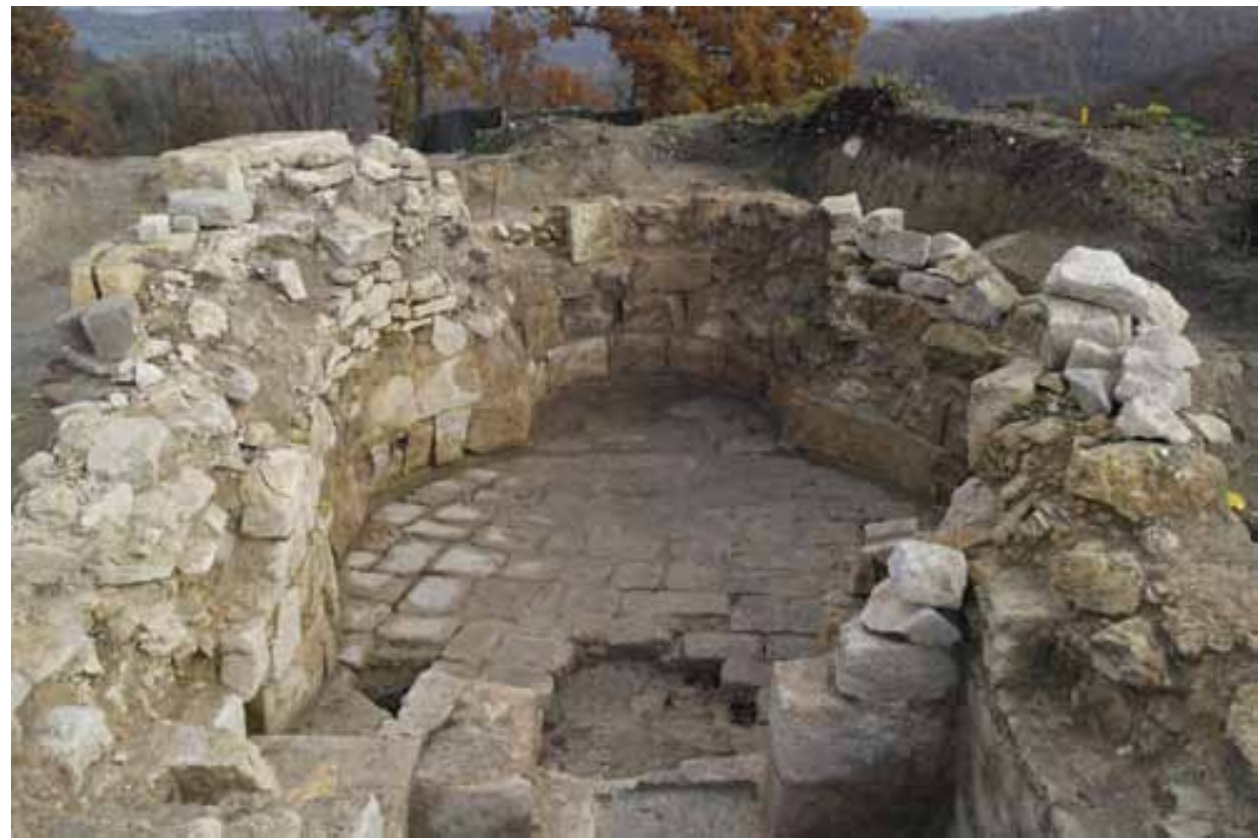

Slika 10. Lokalitet Njive - Ivandol, ulaz u pravokutnu prostoriju i popoločenje rotunde na lokalitetu Njive - Ivandol, pogled s jugozapada (foto: M. Mihaljević)
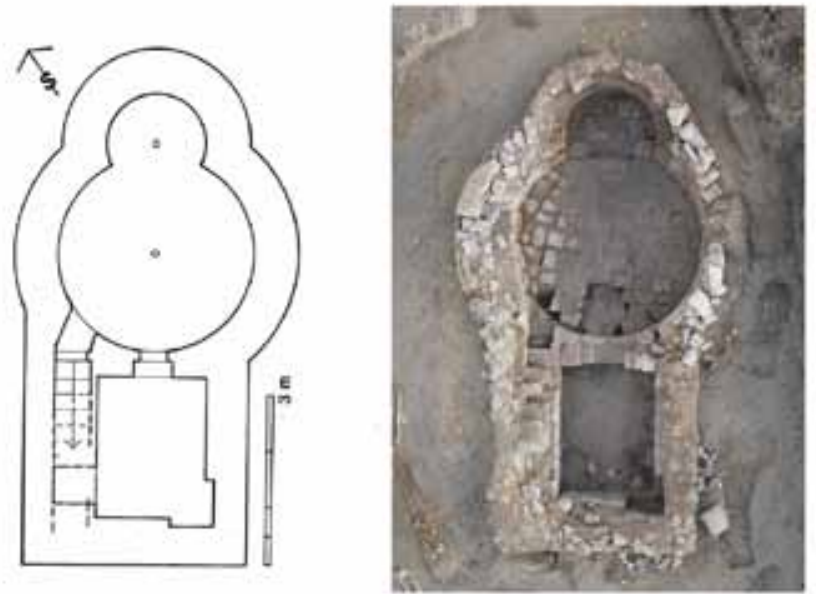

Slika 11. Tlocrt rotunde na lokalitetu Njive - Ivandol, donja etaža, arhitektonska snimka (zanemarena su oštećenja, (crtež: Z. Horvat) 


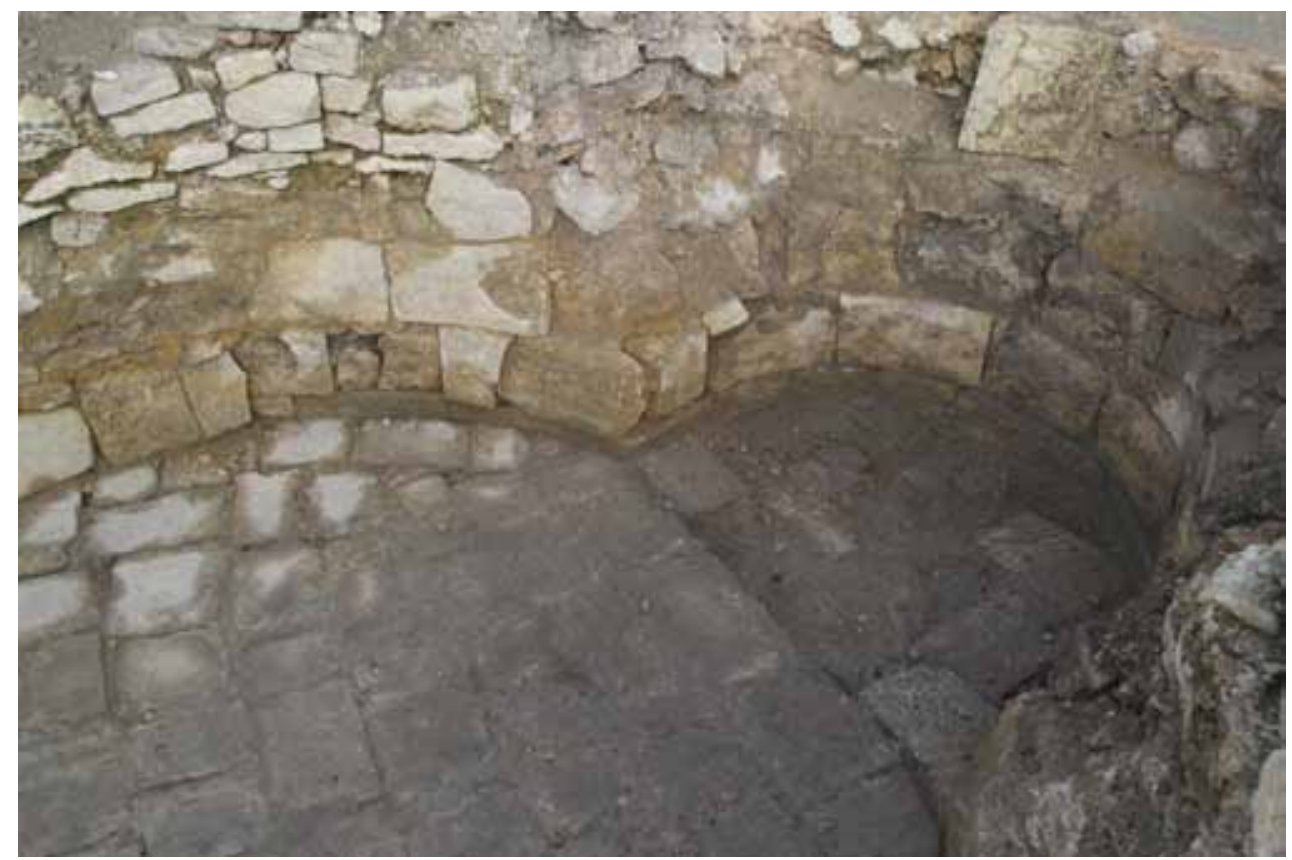

Slika 12. Unutrašnjost apside na lokalitetu Njive - Ivandol, kameno popločenje poda u apsidi (foto. M. Mihaljević)

Tijekom istraživanja pronađen je veći broj manjih ulomaka arhitektonske plastike, uglavnom dijelovi kvalitetno zamišljenih i klesanih arhitektonskih elemenata. Među pronađenim ulomcima ističu se dijelovi okvira portala ili sličnih otvora (torus i polutorus profilacije), ulomak nadvoja romaničke bifore (sl. 13) s ležajem za ugradnju kružnog stupa, ulomci nadvoja, prozora, moguće i prozorske tranzene (sl. 14), a tu je i polukružni nadvoj malog raspona (sl. 15), romaničkih značajki - možda dio okvira svetohraništa. Zanimljivo je da na samoj građevini nije nađen nijedan, izvorno ugrađen, profiliran kameni detalj, ali gornja, danas nama potpuno nepoznata etaža moguće kapele, morala je biti obilatije ukrašena profiliranim pojedinostima. Kvalitetno klesani detalji i njihova brojnost ukazuju na to da je rotunda nesumnjivo bila namijenjena nekom imućnom feudalcu, pretpostavljamo banu Boriću, iako su neki grublje izrade, pa treba biti oprezan $u$ donošenju zaključaka - možda je gruba površina nastala uslijed slabije kvalitete materijala krupnozrnatog pješčenjaka koji je ugrađen na vanjsku stranu građevine, pa je tijekom vremena mogao stradati od atmosferilija. I kasnije rušenje građevine moglo je jednako tako pridonijeti stradavanju ploha kamena (Mihaljević, Horvat, Matković, 2015). Isto tako, nije sigurno da sva arhitektonska plastika potječe izvorno s gornje etaže rotunde. 


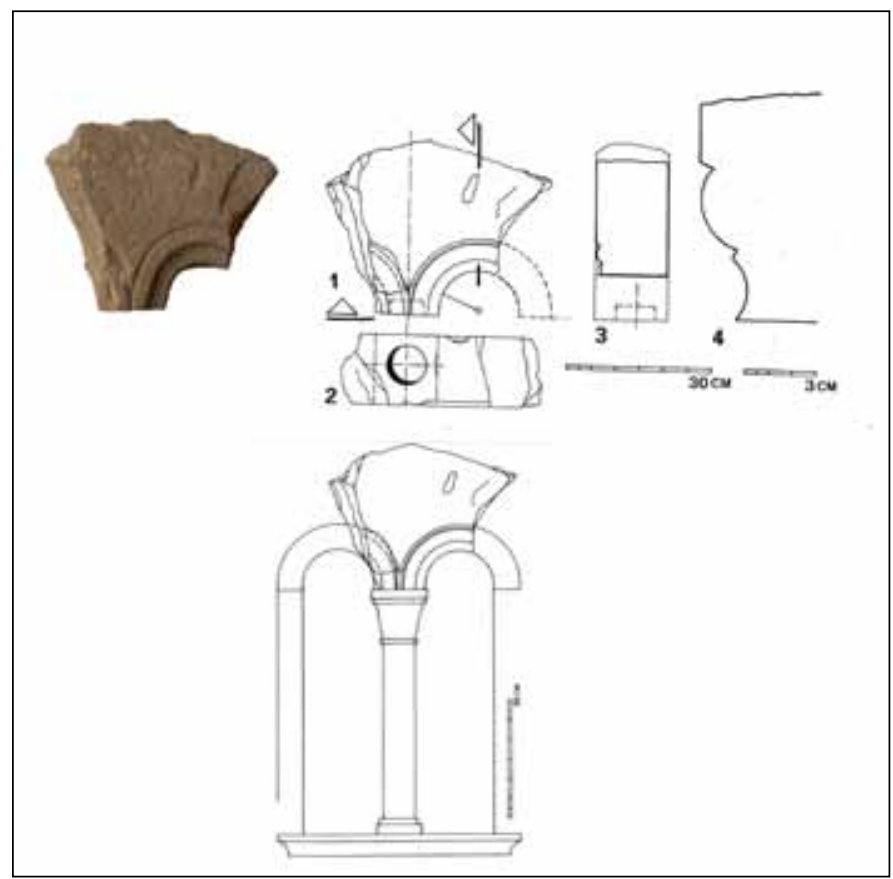

Slika 13. Lokalitet Njive - Ivandol, prikaz profilacija nekih kamenih ulomaka, nadvoj romaničke bifore, pogled i presjeci i pokušaj rekonstrukcije (crtež: Z. Horvat)
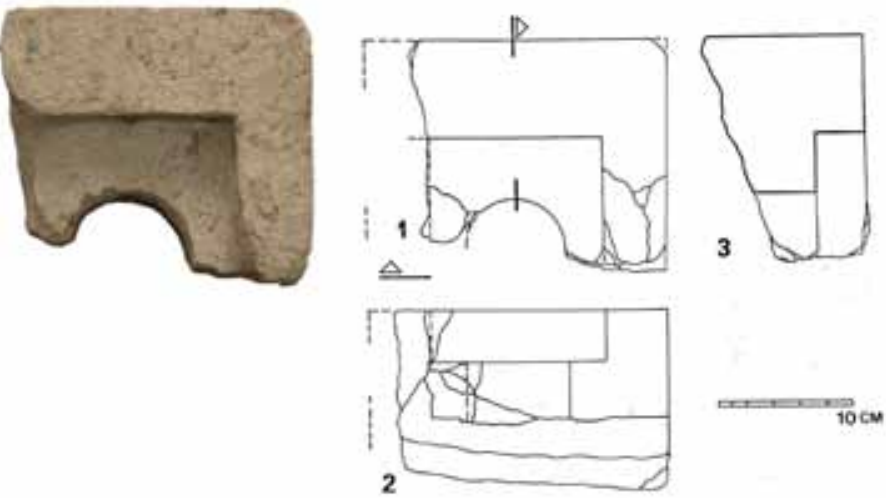

Slika 14. Lokalitet Njive - Ivandol, ulomak tranzene ili kružišta (?), pogled i presjeci (crtež Z. Horvat) 


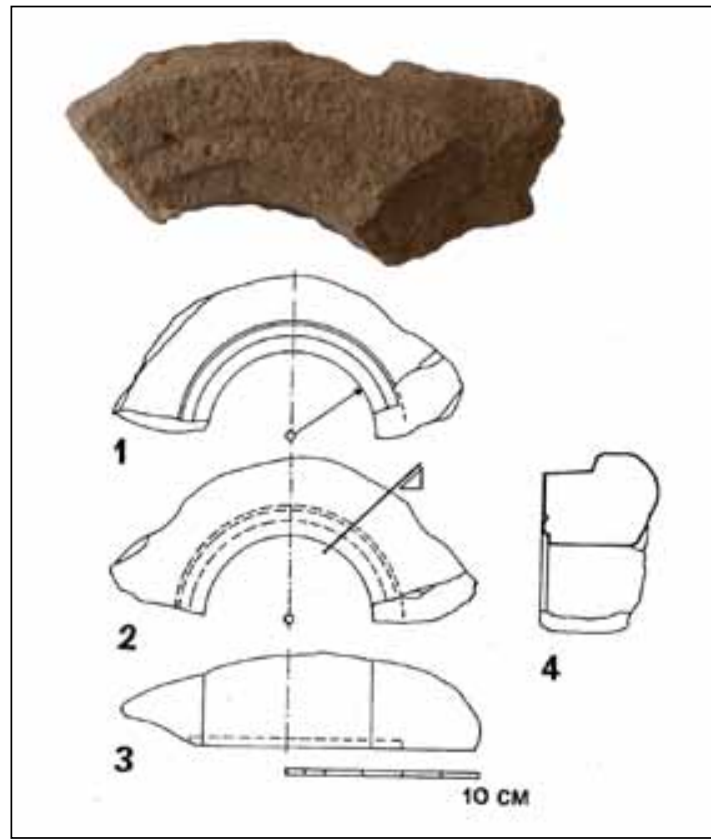

Slika 15. Lokalitet Njive - Ivandol, ulomak lučnog nadvoja, pogled i presjeci (crtež: Z. Horvat)

\section{ROTUNDE U HRVATSKOJ}

Danas možemo kod nas nabrojiti dvadesetak rotundi koje su ostale zabilježene kroz povijesne izvore i kanonske vizitacije, otkrivene arheološkim istraživanjima ili rotunde koje su djelomično ostale očuvane u dijelovima pojedinih današnjih crkava. Među povijesne izvore o rotundama u prvom redu ubrajamo dokumente nastale otprilike u vrijeme kada su nastale i crkve, a ujedno su to i najvažniji izvori, iako ih je vrlo malo do danas objavljeno. Tu se ubrajaju razne darovnice, kupoprodajni ugovori, sudske presude, popisi župa i sl., gdje možemo pratiti pojavljivanje pojedine crkve i pratiti njezin kontinuitet kroz stoljeća. Najvažniji nam je takav dokument popis župa iz 1334. godine koji je sastavio arhiđakon Ivan Gorički u statutima Zagrebačkog kaptola, koji su kasnije objavili Franjo Rački 1872., Ivan Krstitelj Tkalčić 1874. te Josip Buturac 1944. i 1984. ${ }^{4}$ Vrijedan izvor informacija o crkvama sadrže i kanonske vizitacije, koje se počinju bilježiti početkom 17. stoljeća, te u njima nalazimo opširne opise crkava - od opisa zatečenog stanja, popisa inventara, opisa pojedinih graditelj-

4 Radi se o djelima: Tkalčić, I. K., Monumenta historica episcopatus Zagrabiensis I i II, Zagreb 1874.; Rački, F., Popis župa zagrebačke biskupije 1334. i 1501. godine. Starine JAZU, knjiga IV, str. 201-229, Zagreb 1872.; Buturac, J., Popis župa zagrebačke biskupije od godine 1334. Zbornik zagrebačke biskupije 1044-1944. Zagreb 1944.; Buturac, J., Popis župa zagrebačke biskupije 1334. i 1501. godine. Starine 59. Zagreb 1984., str. 43-107 
skih intervencija u smislu popravaka ili preuređenja i sl. Manjkavost tih izvora jest u tome što se uglavnom ne navodi vrijeme nastanka crkve već se starije crkve navode samo kao ecclesia antigua (Vukičević-Samaržija, 1993).

Pregled više ili manje sačuvanih rotundi u našim kontinentalnim krajevima pokazuje njihov dosta mali broj, što je možda posljedica ne samo povijesnih okolnosti već i činjenice da se u jednom trenutku (14. stoljeće?) odustalo od njih i od odlaganja kostiju pokojnika u rotunde - karnere. Rotunde su pripadale romaničkoj arhitekturi, a konačno sam kružni oblik nije se uklapao u gotičke kanone.

Stanje i poznavanje rotundi možemo podijeliti u nekoliko kategorija, prema njihovoj sačuvanosti:

1. Rotunde otkrivene arheološkim istraživanjima

2. Rotunde u zapisima naših istraživača i pisaca

3. Rotunde ugrađene u svetišta kasnosrednjovjekovnih i baroknih crkava ili crkava pregrađenih u kasnijim vremenima

4. Dubiozni objekti: rotunda ili ,trolist"?

5. Moguće rotunde prema istraživanjima P. Gossa 2012. (koje bi se mogle potvrditi budućim istraživanjima na terenu ili ne).

\section{Rotunde otkrivene arheološkim istraživanjima}

1.1. Rotunda Njive - Ivandol (sl. 16), vjerojatno najstarija i uz to, prema ostalim nalazima, bila je najkvalitetnije izvedena.

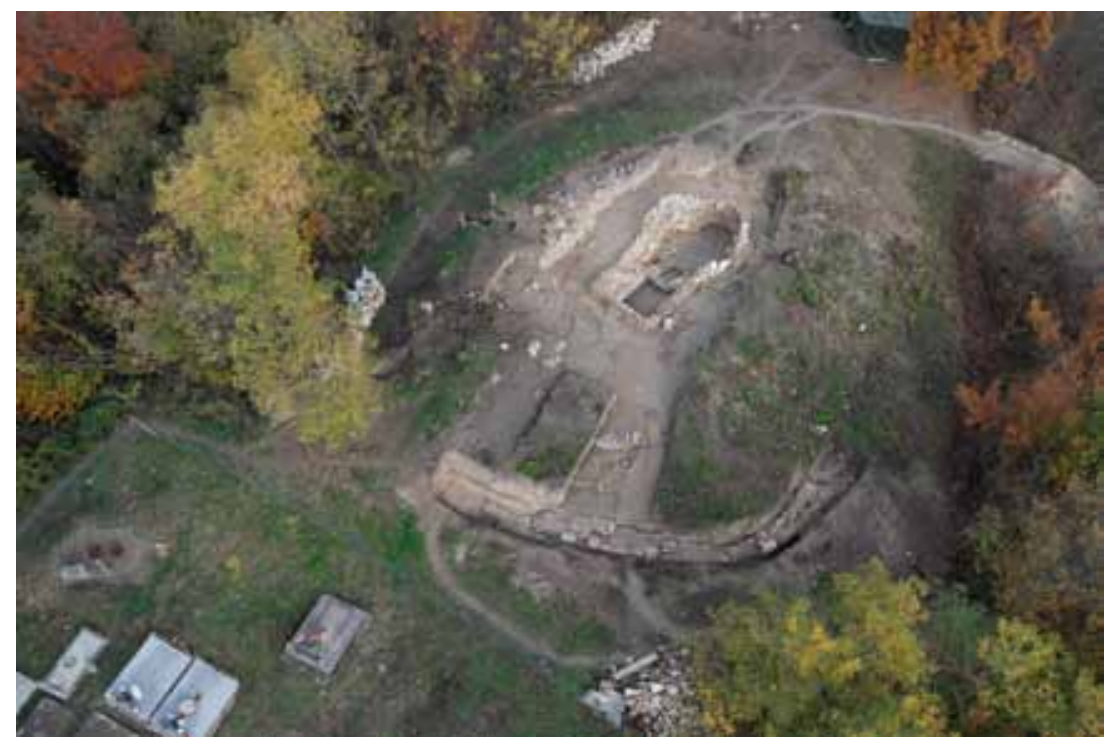

Slika 16. Zračna snimka rotunde na lokalitetu Njive - Ivandol, uz staro groblje (foto: M. Hucaljuk) 
1.2. Dolac (Brestovac) kod Požege - Sv. Kuzma i Damjan - udaljena je od Ivandola kojih 7 km zračne linije, u šumskom predjelu Kuzma, južno od sela Dolac. Tu je rotundu 1997. godine istraživao Gradski muzej Požega pod vodstvom arheologinje D. Sokač Štimac. Otkriveni su temelji rotunde s polukružnim svetištem, ukupnog promjera $840 \mathrm{~cm}$ (sl. 17) te brojni nalazi željeznih čavala i ljudskih kostiju, koji sugeriraju ukope unutar rotunde. Prikupljeno je i dosta ulomaka vapnene žbuke s tragovima oslika geometrijskih motiva. Pretpostavlja se da se radi o dvorskoj kapeli iz 13. stoljeća, s obzirom na blizinu staroga grada Dolca (Vukičević-Samaržija, 2004).

1.3. Prelog - uz župnu crkvu sv. Jakoba, a radi se o kapeli Sv. Duha, poznatoj iz kanonskih vizitacija, čije je postojanje otkriveno 1997. godine. Arheološka je istraživanja vodio arheolog Josip Vidović iz Muzeja Međimurja u Čakovcu. Otkrivena je rotunda s plitkom polukružnom apsidom na istoku, a utvrđeno je da je služila kao karner s kapelom u gornjoj etaži (sl. 18). Vizitatori navode da se nalazila usred groblja, što je potvrđeno pronalaskom kosturnih ukopa uokolo rotunde, te da je na zapadnoj strani imala predvorje, ispod kojeg se nalazila zidana grobnica za pohranu lijesova (Korunek 2012: 83-89).

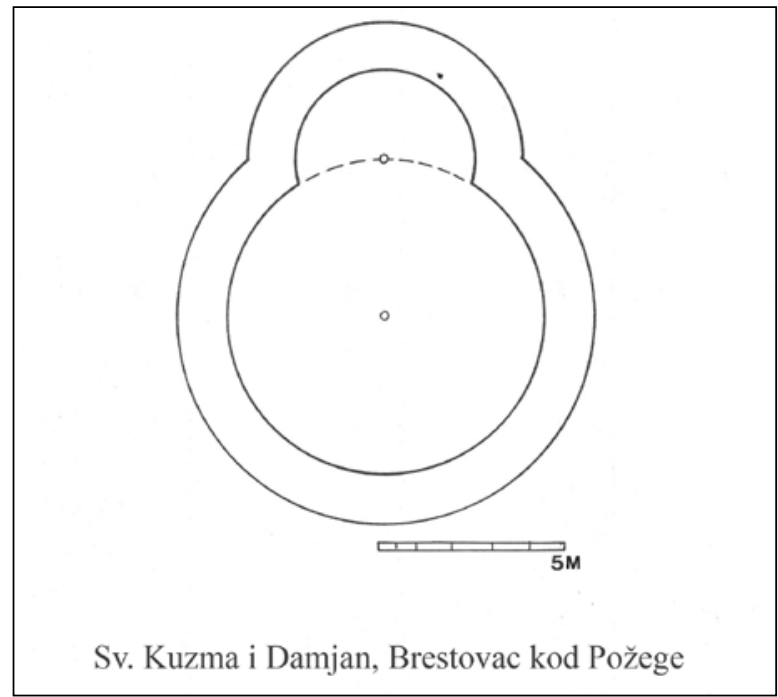

Slika 17. Brestovac kod Požege, tlocrt temelja rotunde na poziciji srednjovjekovne crkve sv. Kuzme i Damjana (crtež: Z. Horvat) 


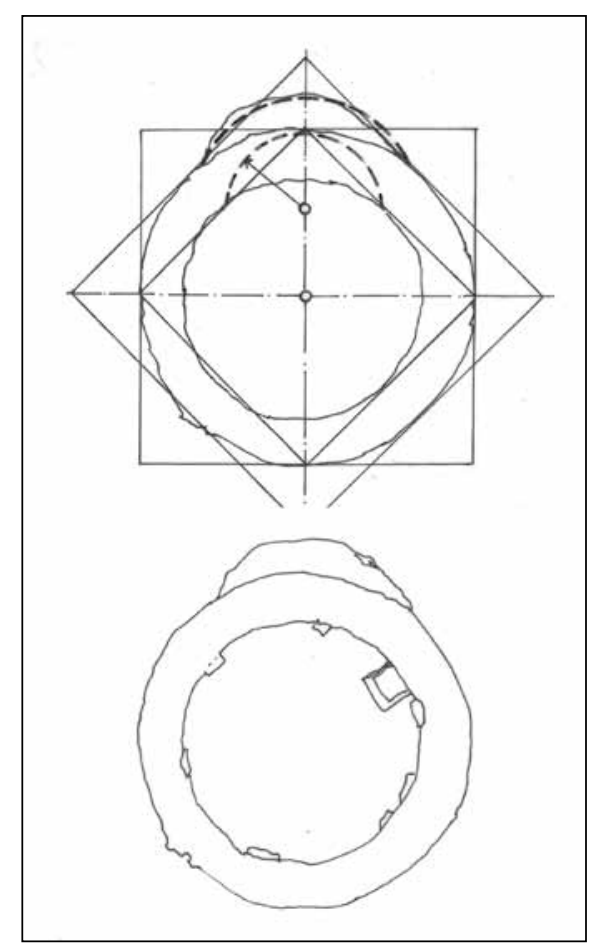

Slika 18. Prelog, temelji karnera kraj župne crkve sv. Jakova, tlocrt temelja (crtež: B. Špoljar u: Korunek 2014: 84) i pokušaj rekonstrukcije apside (crtež: Z. Horvat)

1.4. Zelingrad - Kladeščica: L. Dobronić u svojim je istraživanjima okolice Sesveta i Svetog Ivana Zeline opisala kružni objekt uz temelje crkve sv. Kuzme i Damjana (sl. 19). Prvotna su razmišljanja bila da se radilo o rušenju crkve i izgradnji kule, no razmatranja o rotundama dovela su do pretpostavke da bi to mogao biti karner (L. Dobronić 1979: 65-70). U tijeku su istraživanja Muzeja Sveti Ivan Zelina (Houške, M., i Mačković, R.).

1.5. Zrinski Topolovac - moguća rotunda nalazila se u Zrinskom Topolovcu, gdje su 2002. godine otkriveni temelji kružne građevine, zidane opekama, prigodom zaštitnih radova oko crkve. Nad tim je temeljima kasnije izgrađena gotička župna crkva sv. Mihaela (sl. 20, crtež: Zorislav Horvat). 


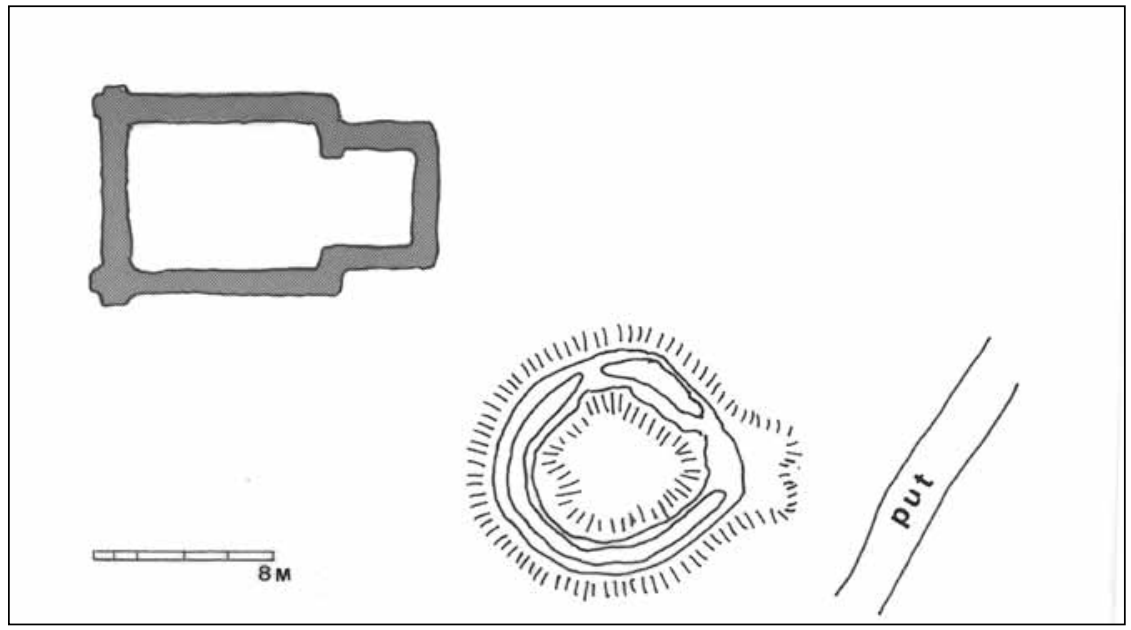

Slika 19. Položaj Kladeščica kraj Zelengrada: tragovi temelja crkve sv. Kuzme i Damjana te kružne građevine, mogućeg karnera (crtež: Z. Horvat)

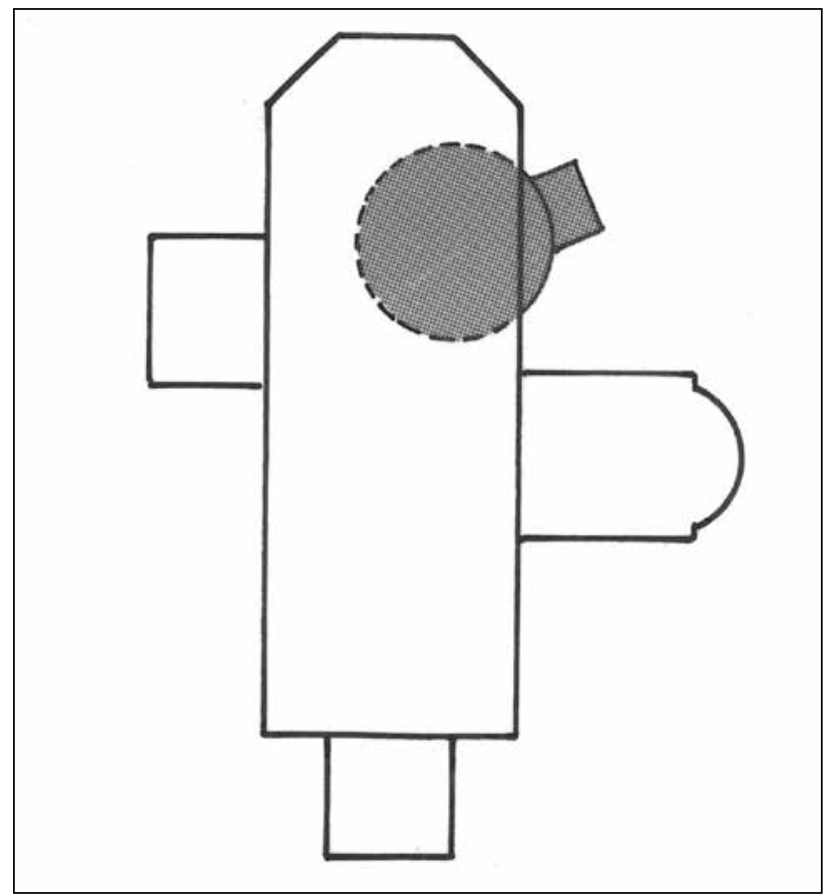

Slika 20. Zrinski Topolovac (zapadno od Bjelovara), župna crkva sv. Mihaela: shematski prikaz ostataka temelja ispod svetišta srednjovjekovne, barokizirane crkve (crtež: Z. Horvat) 
1.6. Najnovije se otkriće pojavilo u Dalmaciji u blizini Trogira, lokalitet Brečevo ${ }^{5}$, gdje su otkriveni ostatci rotunde oko koje je formirano groblje (sl. 21).Također su ispod te rotunde otkriveni ostatci ranosrednjovjekovne crkve, što svjedoči o dugom kontinuitetu korištenja tog prostora kao sakralnog.

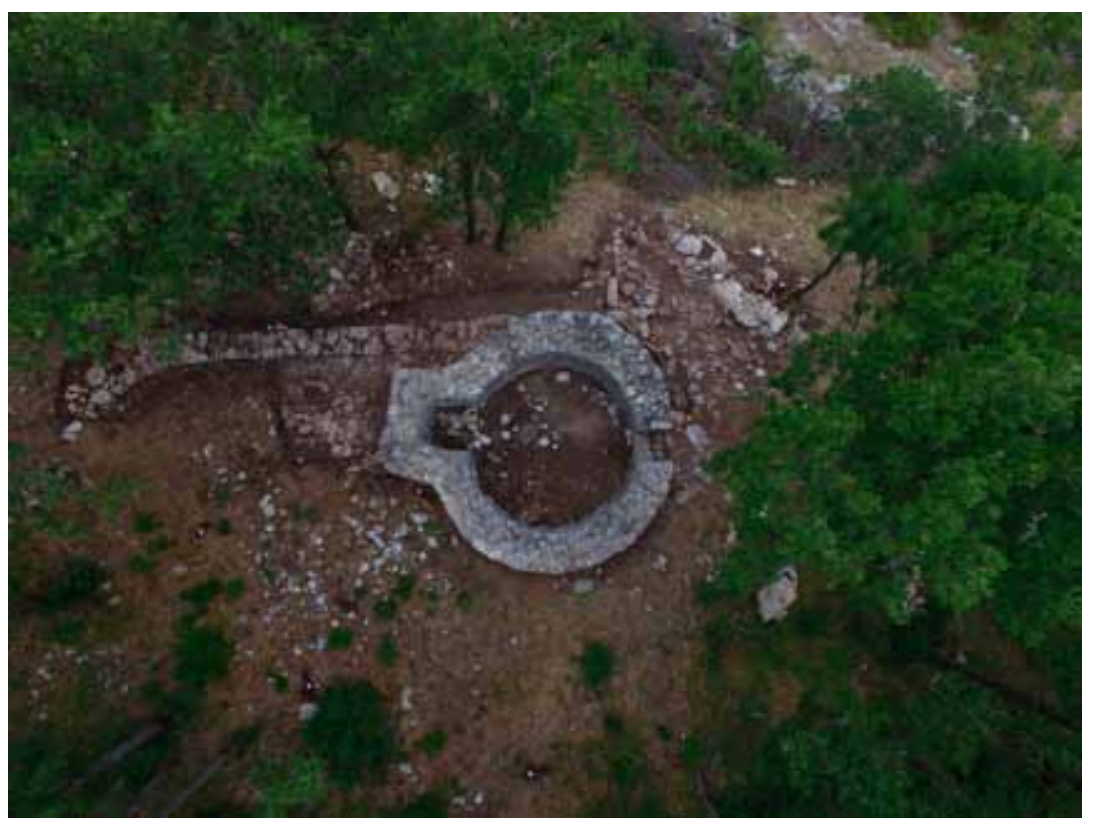

Slika 21. Brečevo, kraj Trogira, zračna snimka (ustupio: konzervator Miroslav Katić, Ministarstvo kulture RH u Trogiru)

\section{Rotunde u zapisima istraživača (Barle, Szabó, a. Horvat, Vukičević-Samaržija, Goss)}

Poneke su crkve i rotunde zabilježene u sjećanjima pisaca i istraživača koji su obilazili teren i vrijedno prikupljali podatke o pojedinim spomenicima. Napose su nam vrijedan izvor terenske zabilješke Anđele Horvat - Putne bilješke, koje se čuvaju u Nadbiskupskom arhivu u Zagrebu.

2.1. Brekinjska kod Pakraca - A. Horvat bilježi mogućnost postojanja karnera kod tog lokaliteta, gdje su, prema kazivanju mještana, kraj groblja nađeni ostatci temelja neke građevine te mnoštvo ljudskih kostiju A. Horvat 1985: 78).

5 Podatke i fotografije rotunde u Brečevu ustupio nam je dr sc. Miroslav Katić, pročelnik Konzervatorskog odjela u Trogiru, kojemu ovim putem zahvaljujemo. 
2.2. Dragović, crkva sv. Stjepana - Gjuro Szabó, opisujući Liješnicu, dotiče se burga Čaklovca te crkve sv. Stjepana „ispod“ njega. U selu Dragoviću spominje još i okruglu kulu u blizini te crkve (Szabó 1908-1909: 42). Možemo pretpostaviti da se radi o rotundi.

2.3. Odra u Turopolju - J. Barle u svojoj povijesti turopoljskih župa navodi podatke iz vizitacija, da je u Odri, na tamošnjem groblju, nekad bila obla kula, koja je služila za borbu s Turcima (Barle 1930: 52). A. Horvat međutim zaključuje da je to bio stariji karner kojem je prenamijenjena uloga (A. Horvat 1984-1985: 80).

2.4. Obrež kod Varaždina, kapela sv. Mihajla u Črešnjevu - primjer crkve koja se navodi kao rotunda, sačuvane iz povijesnih izvora, a kapela je sv. Mihajla u Črešnjevu na posjedu srednjovjekovne župe sv. Ilije u Obrežu (Vukičević-Samaržija 1993: 238-239). Godine 1695. navodi se podatak da kapela postoji još od 1287. godine. Pronađen je i podatak koji govori da je bila zidana rotunda, oko koje se nalazilo groblje. U 18. stoljeću potpuno je zapuštena te danas na tome mjestu nalazimo novu građevinu iz 1981. godine. Prema kazivanjima mještana koji su sudjelovali u gradnji, stara kapela nije nikada dokraja porušena već je samo proširena.

2.5. Križevci, crkva Sv. Križa - još jedna moguća rotunda očuvana u povijesnim izvorima na položaju je današnje crkve Sv. Križa u Križevcima. U izvorima se spominje zdenac (Tkalčić 1887: 287-300), koji je stajao iza današnjeg svetišta crkve: moguće je da se radi o ostatcima romaničke polukružne apside ili možda čak i rotunde, koja bi se nalazila na mjestu današnjeg svetišta ili iza njega (Z. Horvat 2005: 29).

Međutim, razmatrajući postojanje raznih rotundi - karnera, moralo se odustati od prvobitnih zaključaka: možda je tradicija zamijenila kružni tlocrt karnera i identificirala ga sa zdencem?!

2.6. Kamenica kod Lepoglave - iz pisanih nam je izvora poznato da je u Kamenici kod Lepoglave 1354. godine postojala župna crkva Svih svetih, a kanonska vizitacija 1639. godine spominje ondje „okruglu“ crkvu. Prema kanonskoj vizitaciji iz 1640. godine, ondje je podignuta crkva sv. Bartola, pri čemu je stara crkva kružna tlocrta poslužila kao sakristija koja je porušena 1726., a njezin zvonik 1825. godine (Vukičević-Samaržija, 1993: 20; Goss, 2012: 89-90).

2.7. Glogovnica - kružni objekt spominje se u zapisu kanonske vizitacije 1707. godine (vizitator je J. Bedeković): „,od temelja zidana dotrajala mala građevina kružna oblika..." (A . Horvat, 1961: 31), a smještena je Prope deinde fundum Parochialem... Objekt je očito bio smješten negdje kraj župne kurije. A. Horvat još pretpostavlja da se radi i o romaničkom karneru, dakle možda i iz doba "prije Tatara“, što ne treba čuditi s obzirom na nedavne nalaze vjerojatno crkve kanonika Sv. groba jeruzalemskog (sepulkralaca/Homen: 22). Temelji te crkve ispod današnje župne crkve pokazuju da se radilo o romaničkoj crkvi, dakle i o ranijoj građevnoj aktivnosti na tom prostoru. 


\section{Rotunde ugrađene u svetišta kasnijih crkava}

3.1. Župna crkva sv. Katarine Aleksandrijske u Samarici kod Čazme jest gotička, s gotičkim brodom i zvonikom, a svetište je prigrađeno starijoj rotundi ili, bolje reći: gotička je crkva prigrađena polovici rotunde. Karakterističan je jedan zaostali romanički prozor na jugoistočnoj strani sačuvana dijela rotunde (sl. 22, 23). Crkva je tijekom vremena bila barokizirana (A. Horvat, 1984-1985: 68) .

3.2. Gojilo - kapela Sv. Duha valjda je jedina u potpunosti sačuvana rotunda (sl. 24, 24a)..., ali je raznim dogradnjama i pregradnjama potpuno izgubila svoj izvorni lik, tako da Lj. Karaman uopće sumnja u njezinu izvornost. Međutim, za Szabu, A. Horvat i A. Bobovec (A. Bobovec 1998: 12-23), to je ipak izvorna srednjovjekovna građevina. Gjuro Szabó pak piše da je to „Nažalost sasvim pogrešnom restauracijom izopačena jedna od naših najzanimljivijih drevnih građevina" (Szabó 1924: 78-79). A. Horvat (1984-1985: 78-79) smatra da je ta građevina izvorno srednjovjekovna, no da je sakristija na sjevernoj strani rotunde kasnije dodana. Goss (2012: 77) naglašava „položaj još starije osmatračnice, položaj na ostrogotskom limesu slavenskog svetog kruga" (?).

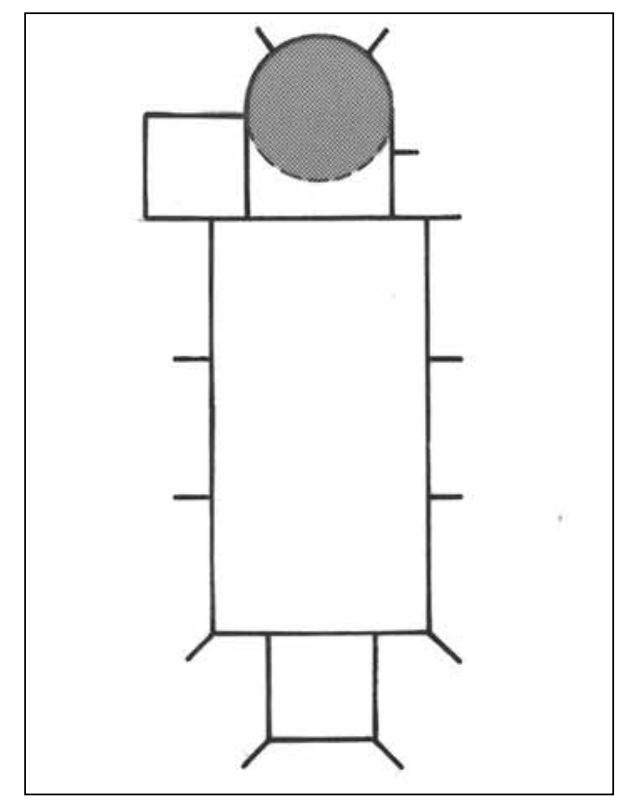

Slika 22. Samarica, župna crkva sv. Katarine, shematski prikaz uključivanja jedne rotunde u kasnogotičku, kasnije barokiziranu crkvu (crtež: Z. Horvat) 


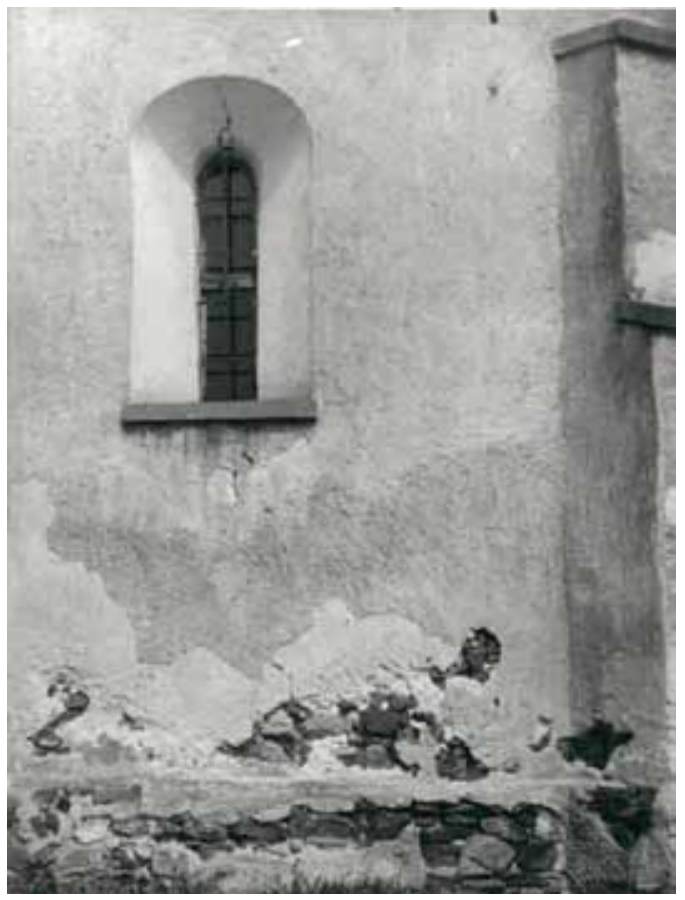

Slika 23. Samarica, župna crkva sv. Katarine, romanički prozor na uključenom dijelu rotunde (foto: Z. Horvat)

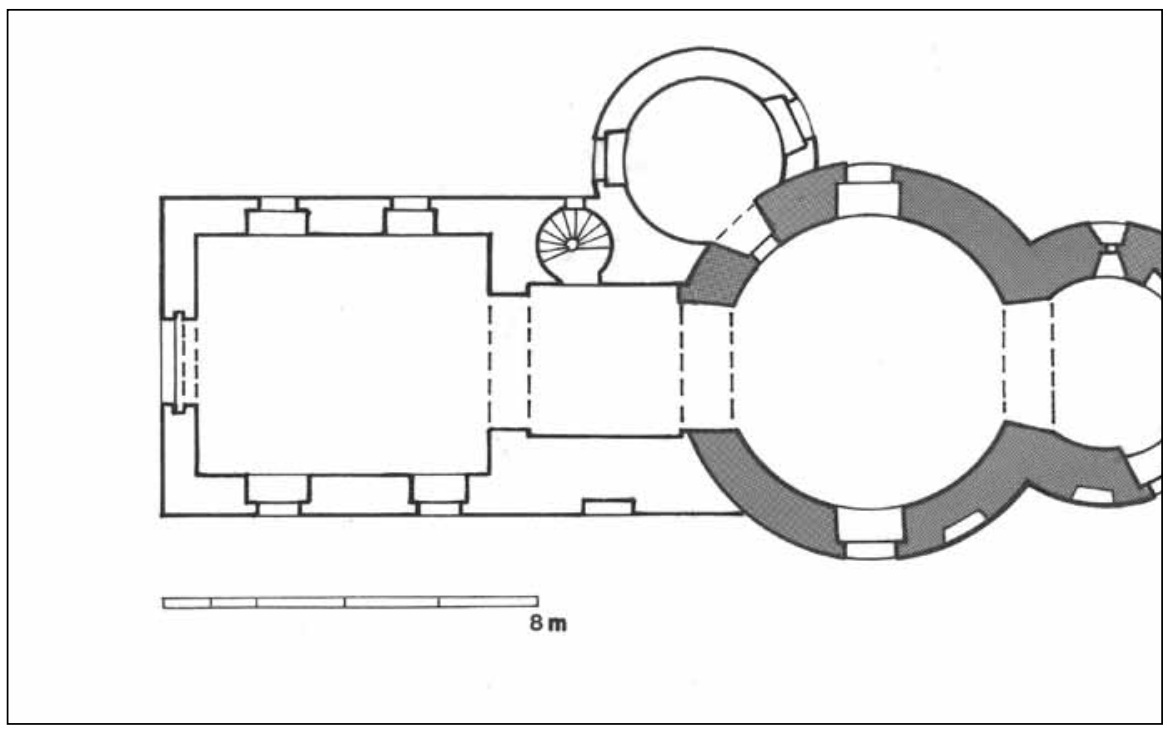

Slika 24. Gojilo - Kutina, kapelica Sv. Duha (crtež: Z. Horvat) 


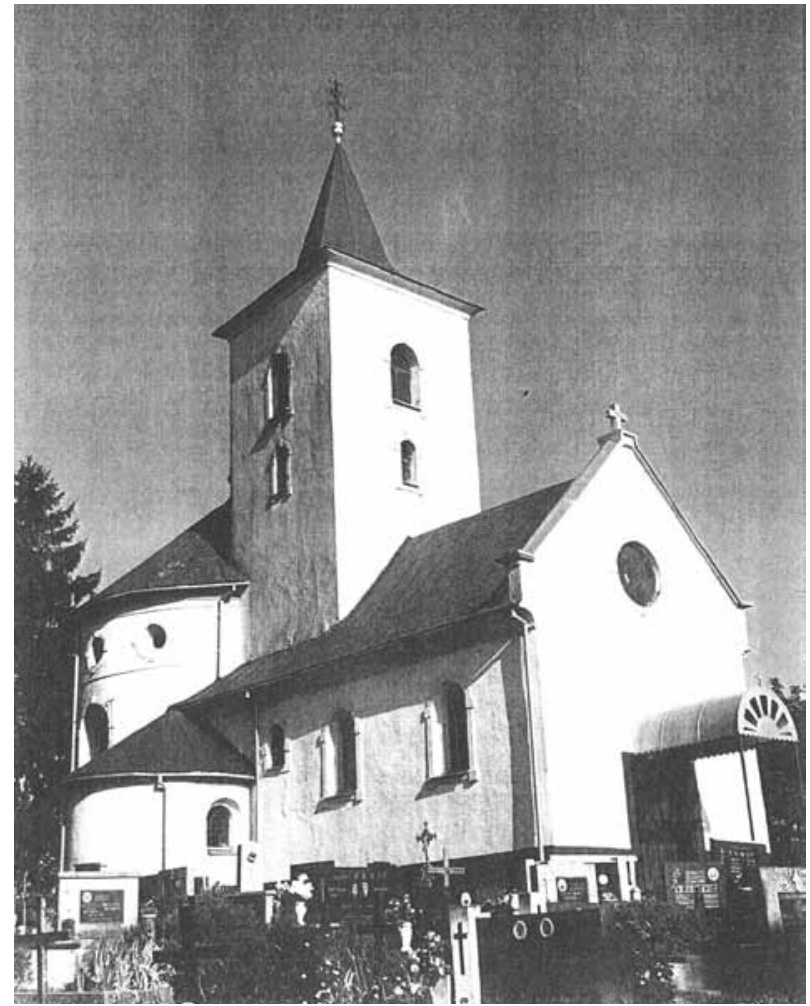

Slika 24a. Gojilo - Kutina, kapelica Sv. Duha

3.3. Otruševec kod Samobora, kapela Sv. Križa na groblju - romanička je to rotunda, kojoj je umjesto izvorne polukružne apside dodano kvadratno svetište, i to još u gotici, te presvođeno gotičkim križnim svodom. Na zapadnoj je strani dodan zvonik i novi ulazni prostor (sl. 25). Nedavna su konzervatorsko-restauratorska istraživanja otkrila mnogo zanimljivih pojedinosti (vodili su ih J. Burmaz i J. Živković, 2007). Izvorna je romanička rotunda bila pokrivena posvuda ravnim stropom, što može biti jedan od razloga da je kasnije dobila gotičko svetište, presvođeno križnim svodom.

\section{Dubiozni objekti: rotunda ili trolist (?)}

4.1. Orljavac kod Požege, kapela sv. Roka - prvotno je smatrana pregrađenom trolisnom kapelom (Szabó 1929: 551), no kasnije su neki autori konstatirali da se ipak radi o romaničkoj rotundi, kojoj je kasnije prizidan odulji pravokutni brod (Z. Uzelac 1984; D. Stepinac (sl. 26) A. Horvat 1984-1985: 80). 


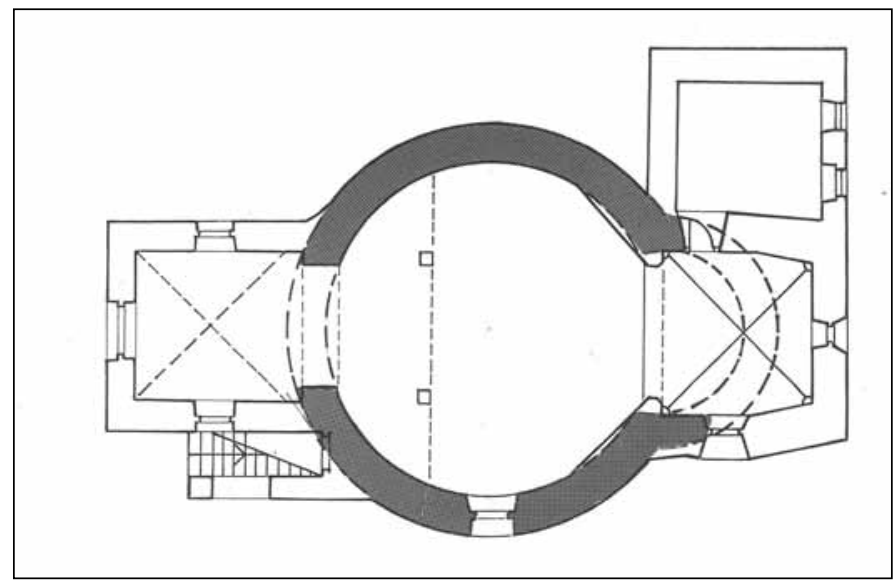

Slika 25. Otruševac kraj Samobora, kapela sv. Križa, tlocrt s prikazom prvotne apside (crtež: Z. Horvat prema snimci J. Živković 2007.)

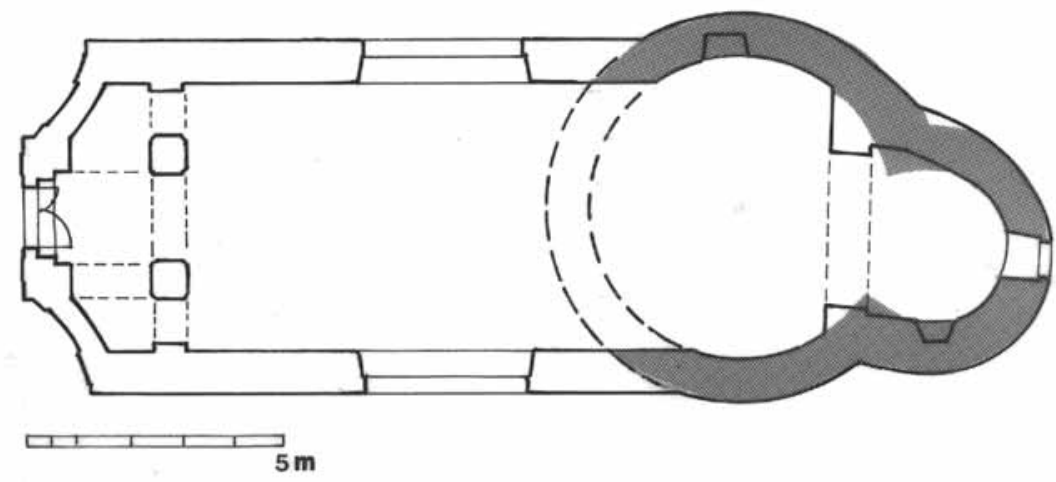

Slika 26. Orljavac, kapela sv. Roka, prikaz prve rotunde (Z. Horvat prema snimci D. Stepinca; A. Horvat, 1985)

4.2. Iž Mali (Dalmacija), kapela sv. Marije, 9. - 12. stoljeće; imala je jednostavan tlocrt rotunde s polukružnom apsidom, kojoj je kasnije prizidan odulji pravokutni brod (T. Marasović, T. Gvozđanović, S. Seskulić-Gvozdanović, A. Mohorovičić, 1978: I.C ) (sl. 27). 


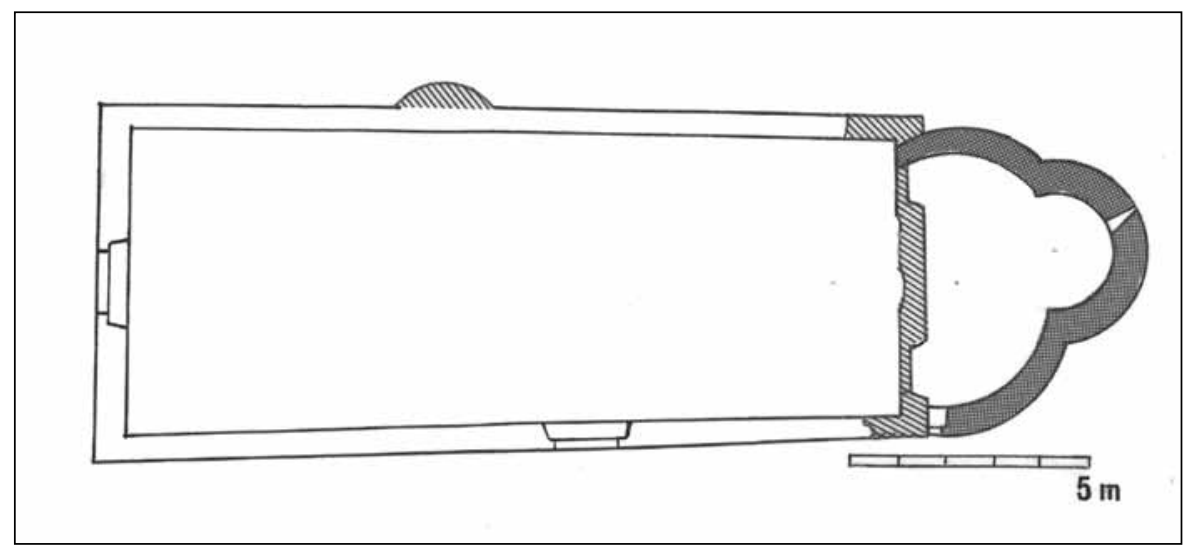

Slika 27. Mali Iž, kapela sv. Marije (crtež: S. Sekulić - Gozdanović 1978.)

4.3. Topusko, crkva sv. Marije sa cistercitskim samostanom iz 13. stoljeća: arheološka istraživanja provedena su $u$ dvije etape $u$ drugoj polovici 19. stoljeća, a djelomično još 1966. (Z. Horvat 1999: 121). Istražen je tlocrt crkve te dio samostana: među temeljima iskopanim 1879. godine izdvaja se dio koji je kružna tlocrta (sl. $28)^{6}$. Ucrta li se puna kružnica tog tlocrta, očito je da je mogao biti srušen prigodom gradnje istočnog samostanskog krila. Istodobno, kao da je crkva pozicionirana tako da ne dira topusku „rotundu“. Je li rotunda još bila u uporabi prije početka radova na svetištu cistercitske crkve? Znači li nešto kraljevska nadarbina, a i njegova kraljevska namjera za njezino korištenje Topuskog kao jedne od postaja na putu u Svetu Zemlju 1217. godine? Ili je to možda jedan od rimskih objekata? Ponovimo da je tih godina bilo uobičajeno graditi „vladarske rotunde“ (Zadnikar 1982: 439). Kasnija tatarska provala mogla je izazvati prekid gradnje crkve i samostana, a i promjenu u projektu i crkve i samostana (Z. Horvat 1999: 129).

\section{Moguće rotunde prema istraživanjima V. Gossa (2012.)}

5.1. Gaj - zapadno od Pakraca, Sv. Helena - „navodno su se vidjele velike ruševine crkve... velika je crkva barokna. U zvoniku bi mogle biti srednjovjekovne spolije... možda i rotunda ispod apside (?) Moguće srednjovjekovna župa Miholec." (V. Goss, 2012: 75; broj objekta 125).

5.2. Igrišče; ispod Velikog Kalnika, ispod ostataka srednjovjekovne crkve nalaze se tragovi kružne zgrade. Međutim, nedavna arheološka istraživanja nisu zasad potvrdila tu pretpostavku (V. Goss, 2012: 89; broj objekta 195).

6 Tlocrt orginala nalazi se u Planoteci uprave za zaštitu kulturne baštine Ministarstva kulture u Zagrebu (crtao 1877. F. Erben, a 1879. naknadno ucrtao Lj. Šimić u Erbenov tlocrt). 


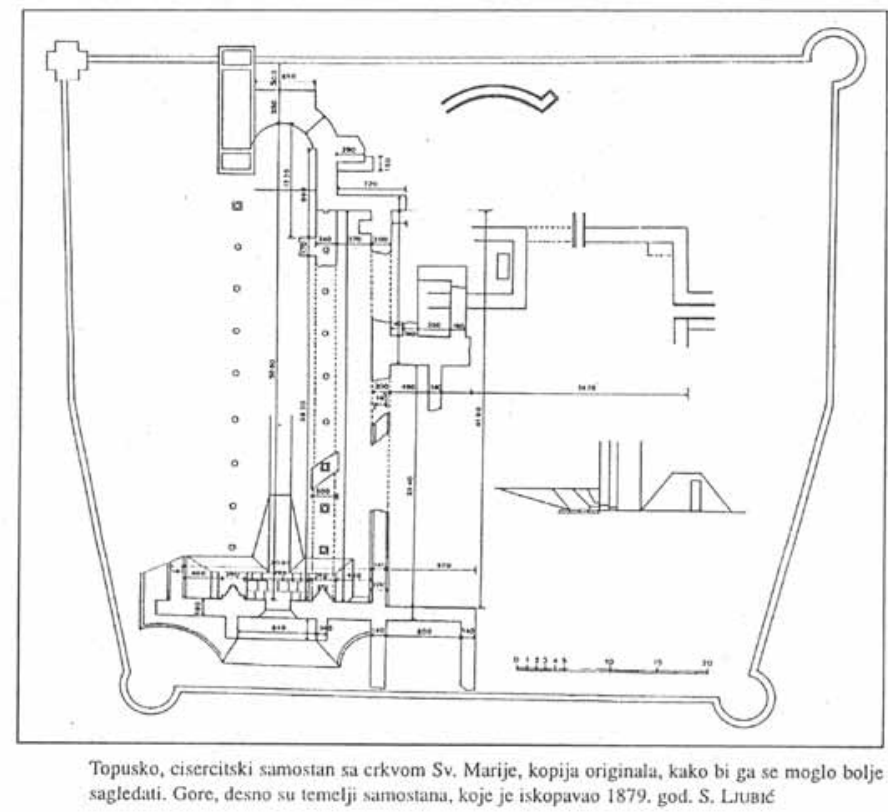

Slika 28. Topusko, cistercitski samostan s crkvom sv. Marije, kopija orginala, kako bi ga se moglo bolje sagledati. Gore, desno su temelji samostana, koje je 1879. god. iskopao Š. Ljubić (precrtao s originala Z. Horvat)

5.3. Selo Kula jušno od Kutjeva, Turci su srušili zidanu crkvu i od nje izgradili kulu; nije li i tu bila rotunda? (V. Goss, 2012: 98; broj objekta 246).

5.4. Ladislav kod Garešnice, „mala kružna utvrda“ uz cestu Ladislav - Velika Trnovitica mogla bi biti i rotunda... (V. Goss, 2012: 100; broj objekta 257).

5.5. Trema - Staro brdo, istočno od Križevaca, spominje se i neka „mala kružna zgrada", koja bi mogla biti i ostatak neke rotunde (V. Goss, 2012: 142; broj objekta 497).

\section{Medvedgrad kod Zagreba ${ }^{7}$}

Na kraju spomenimo kapelu sv. Filipa i Jakova na Medvedgradu nad Zagrebom (Miletić, 2012: 231-232 / sl. 29, 30). Riječ je o već uznapredovaloj prijelaznoj građevini romaničko-gotičkoga stila, čiji je tlocrt srodan romaničkim rotundama, i to onih

\footnotetext{
7 Medvedgradsku kapelu sv. Filipa i Jakova navodimo iz razloga sličnosti i koncepcije njihovih tlocrta. Kod oba ova objekta centralnom brodu je dodano kratko svetište, koncepcijski iste tlocrtne zamisli tj. kao dio kružnice odnosno osmerokuta. Sličnost zamisli očito je u upornost tradicije na prijelazu iz romanike u gotiku i u oblikovnom smislu i u namjeni za vladare i magnate.
} 
Radovi Zavoda za znanstveni i umjetnički rad u Požegi, 7 (2018), str. 55-90 M. Mihaljević; M. Matković; Z. Horvat: Arheološka istraživanja lokaliteta Njive-lvandol...

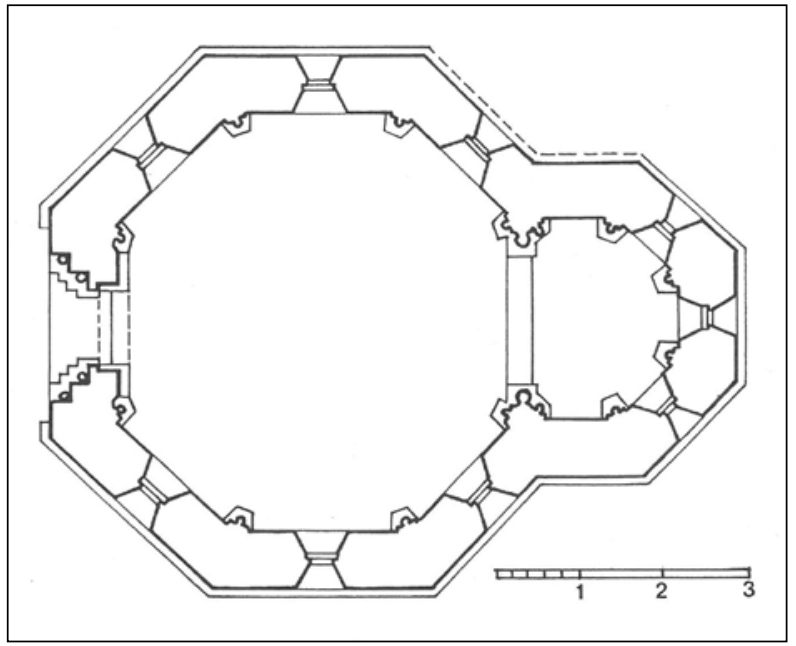

Slika 29. Medvedgrad, kapela sv. Filipa i Jakova, tlocrt (crtež: Z. Horvat prema Miletić - Valjato - Fabris, 1987.)

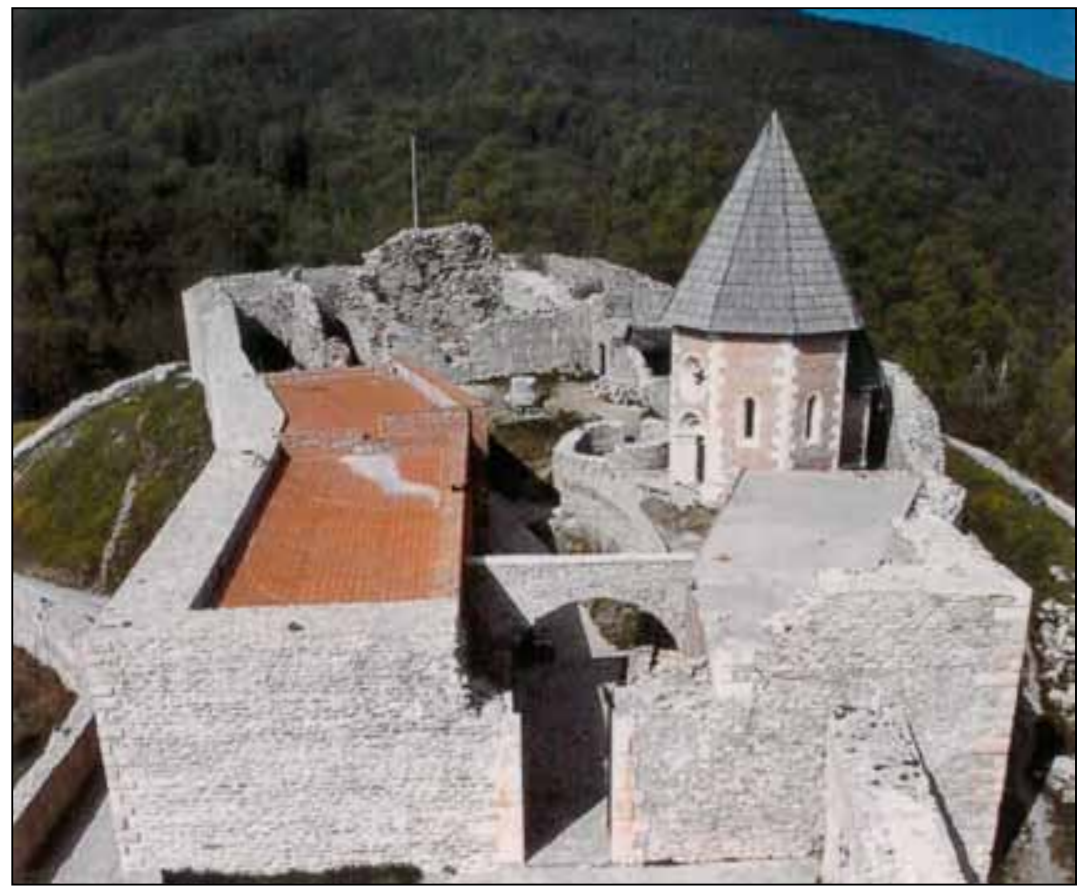

Slika 30. Medvedgrad, kapela sv. Filipa i Jakova, pogled s juga (foto: D. Miletić, 2016.) 
koje su bile namijenjene visokom plemstvu i vladarima (Zadnikar 1982: 438-440). Tu je kapelu gradio zagrebački biskup Filip sredinom 13. stoljeća, navodno za kralja Belu IV. (Miletić, 2012: 256). To dakle potvrđuje osnovnu ideju takvih građevina još od Aachena i dvorske kapele češkoga kralja Vaclava na praškim Hradčanima još iz doba oko 930. godine.

\section{ROTUNDE U EUROPI}

U Hrvatskoj nisu poznati primjeri očuvanih romaničkih rotundi u izvornom obliku, odnosno ne znamo kako su izgledale u punoj veličini,a na prostoru srednjoeuropskih zemalja ostali su sačuvani brojni primjeri romaničkih rotundi u svom izvornom obliku prema kojima možemo pretpostaviti kako su izgledale naše rotunde. U razdoblju romanike rotunde se grade kao dvorske kapele nekih vladara i visokog plemstva (Zadnikar 1982: 439-440), kao samostalne kapele ili kao grobljanske kapele s kosturnicom (karneri) uz župne crkve (sl. 31). Takve građevine, karneri, uobičajeni su za razdoblje romanike, kada postoji običaj da se kosti iz ranijih grobova skupljaju i polažu u zajedničku kosturnicu prilikom novih ukopa. Primjere romaničkih rotundi raznih namjena nalazimo u Sloveniji, Austriji, Češkoj, Slovačkoj, Poljskoj, Mađarskoj i Rumunjskoj, a navest ćemo neke primjere.

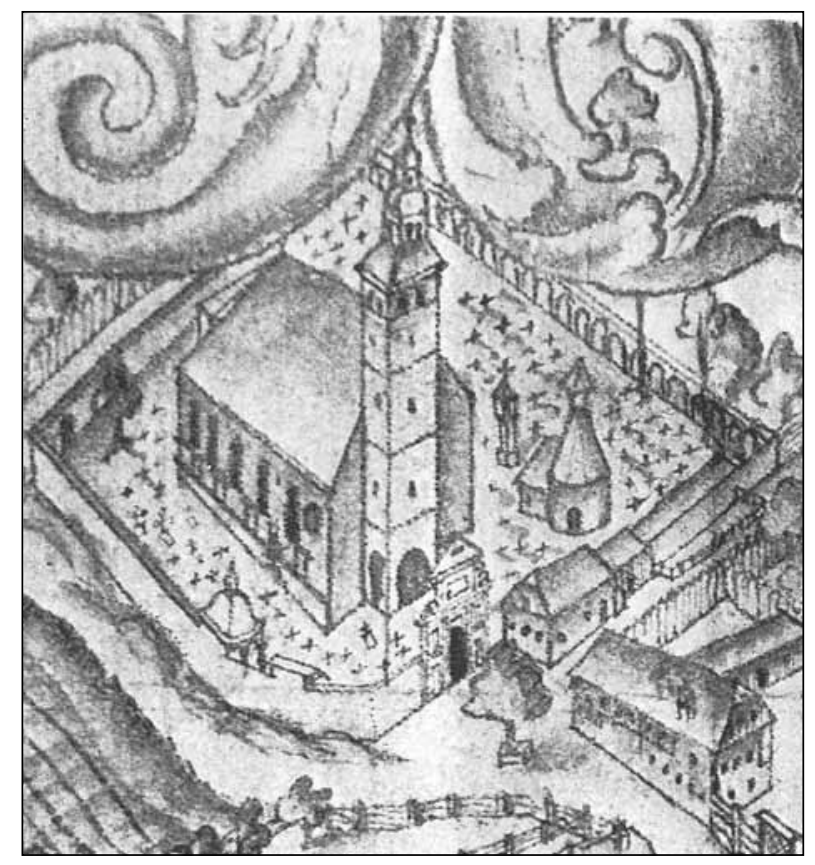

Slika 31. Ljubljana, župna crkva sv. Petra, pogled na smještaj karnera uz crkvu, veduta Ljubljane oko 1700. godine, Zadnikar 1982., slika na str. 478. 
U Sloveniji je među najpoznatijim primjerima romaničkih rotundi svakako kapela sv. Nikole u Selu u Prekmurju, izgrađena u drugoj polovici 13. stoljeća, koja tlocrtno odgovara ivandolskoj rotundi. Ona je po dimenzijama znatno veća - unutrašnji je promjer $6,60 \mathrm{~m}$ te je građena od opeke, međutim građena je dosta kasnije u odnosu na našu iz Ivandola. Još je jedan primjer slovenskih romaničkih rotundi kapela s kosturnicom sv. Mihaela u Gornjem Mokronogu (sl. 32), nastala također u 13. stoljeću, građena od priklesana kamena (Zadnikar 1982: 464).

U Austriji imamo brojne poznate primjere rotundi građenih kao kapele uz župne crkve, a najpoznatije su od njih kapele u Glantschachu, Einersdorfu, Globasnitzu itd. (Korunek, 2012; 88).

U Slovačkoj je također poznato nekoliko primjera, a najpoznatije su rotunde $\mathrm{u}$ Kostolcu, karner sv. Mihovila u Banskoj Stiavnici te crkva sv. Jurja u Skalici. ${ }^{8}$

U Češkoj je više dobrih i kvalitetnih primjera, no konačno čini se da se baš ondje i započelo s vladarskim rotundama: to je velika rotunda sv. Vita na Hradčanima kod Praga s četiri kapele i sa srednjim dijelom bazikalno uzdignutim, a građena je oko 930 godine. No, nama su zanimljivije male rotunde, kakvih je u Pragu bilo više, jednostavna tlocrta, a građenih tijekom 12. stoljeća: to su rotunde sv. Martina (prva trećina 12. stoljeća), Sv. Križa (rano 12. stoljeće) te sv. Longina (prva trećina 12. stoljeća) (Praha sredoveka 1983.). Zanimljiva nam je i crkva sv. Jurja u Ripu s poč. 12. stoljeća (sl. 33).

Najbrojnije primjere rotundi pronalazimo u Mađarskoj, gdje se u doba Arpadovića u 12. stoljeću grade brojne rotunde, kao plemićke kapele i karneri. Procjenjuje se da je postojalo između 80 i 200 rotundi, iako njihov točan broj još uvijek nije poznat (Nemcsics 2012). Nabrojit ćemo samo neke od njih: rotunda sv. Jurja u Veszpremu, sv. Jakova u Jaku (sl. 34), sv. Nikole u Kallcsdu itd. (Szilágyi, 2009.)

\footnotetext{
8 https://www.google.com/maps/place/Rotunda+sv.+Juraja/@48.8484813,17.225406,15z/data=!4m5 !3m4!1s0x0:0x56d18eb185cca3b5!8m2!3d48.8484813!4d17.225406 http://apsida.sk/c/327/skalica https://www.zahorskemuzeum.sk/rotunda-svateho-juraja/
} 
Radovi Zavoda za znanstveni i umjetnički rad u Požegi, 7 (2018), str. 55-90

M. Mihaljević; M. Matković; Z. Horvat: Arheološka istraživanja lokaliteta Njive-lvandol...
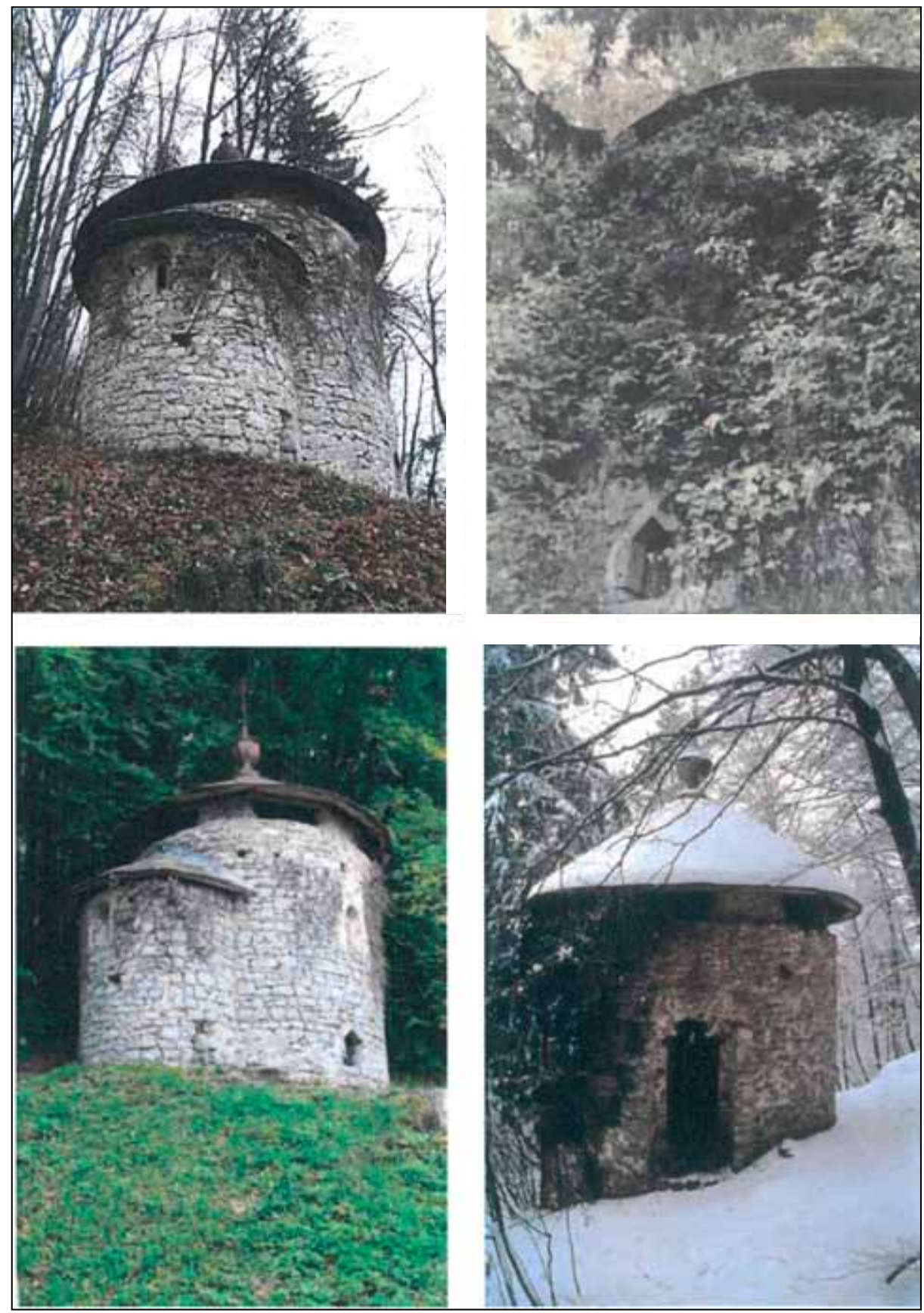

Slika 32. Gornji Mokronog u Sloveniji, kosturnica sv. Mihaela 


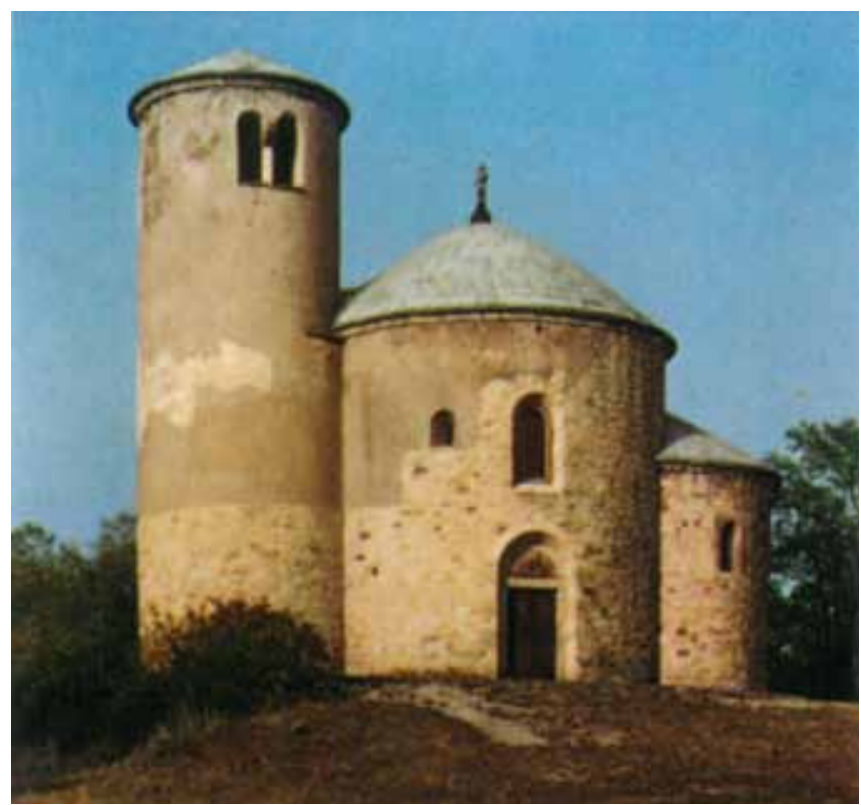

Slika 33. Rip, Češka, kapela sv. Jurja (Jiří) oko 1126. godine (1980.)

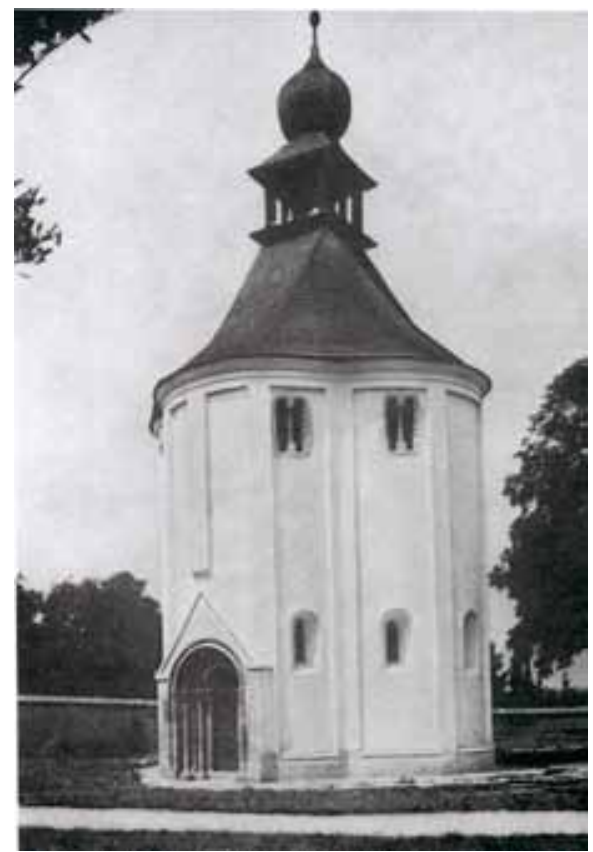

Slika 34. Ják, Mađarska, četverolisna kapela pred benediktinskom crkvom u Jáku: karakteristična katna gradnja s biforama (foto: 1981., slika 145) 


\section{Zaključna razmatranja}

Rotunda na lokalitetu Njive - Ivandol iznimno je važna za istraživanje požeškoga srednjovjekovlja, ali i srednjovjekovlja Slavonije općenito. Zahvaljujući dosadašnjim istraživanjima, pretpostavljalo se da su se u Slavoniji tijekom srednjega vijeka sakralni objekti uglavnom radili od drva te su tijekom vremena iščezli. Međutim, iako danas raspolažemo vrlo malim brojem zidanih sakralnih objekata iz razdoblja srednjega vijeka na prostoru Slavonije, svakim takvim otkrićem dokazuje se da kamene građevine baš i nisu bile rijetkost na ovim prostorima, kao što nisu rijetkost ni u ostalim susjednim zemljama. To se potvrđuje i konzervatorskim i arheološkim istraživanjima nekih današnjih crkava, gdje se u velikom broju ispod barokiziranih zidova pronalaze tragovi romanike ili gotike. Ivandolska rotunda još je jedan primjer centralnog tipa sakralne gradnje u ovom dijelu Požeške županije, uz primjere iz Orljavca i Dolca (moguće i Brestovca). Na relativno malom prostoru poznate su čak četiri kamene rotunde, što je već dovoljno da se tvrdnje o rijetkosti kamene gradnje u vremenu romanike odbace, barem ako je riječ o ovom dijelu Požeške županije.

Iako se na prvi pogled čini da su romaničke rotonde rijetkost u srednjovjekovnom graditeljstvu kontinentalne Hrvatske, navedeni primjeri pokazuju da ih se ipak gradilo, a o njihovu stvarnom broju možemo samo nagađati. Rotunde variraju u svojim dimenzijama i tlocrtnim rješenjima, pa i namjenama, no ipak su bliske jedna drugoj i mogu se usporediti i s brojnim primjerima romaničkih rotundi u srednjoj Europi. U srednjem vijeku prostor Požeške kotline bio je većim dijelom u rukama plemića, stoga se možda požeške rotunde mogu smatrati izrazom plemstva, koje je, možda po uzoru na srednjoeuropsko, gradilo svoje privatne kapele ili grobnice u obliku rotundi. Odgovor nam možda pruža ivandolska rotunda - karakteristike romaničke gradnje koje se očituju u oblikovanju tlocrta i načinu gradnje klesancima, kakvi su u Slavoniji zabilježeni još samo na obližnjoj benediktinskoj crkvi u Rudini (12. - 13. st.), templarskoj utvrdi kod Račeše (13. st.) te na ulaznoj kuli Bedemgrada kod Našica (oko 1300. godine). Pronađeni arhitektonski elementi koji svojom kvalitetom izrade odgovaraju kvalitetnom arhitektu i klesarima te izvrsnost graditelja koja se očituje i u izvedbi tlocrta i usklađenosti detalja ukazuju na činjenicu da je u razdoblju romanike objekt takve kvalitete mogao naručiti samo netko tko je imao dovoljno financijskih sredstava i utjecaja. Moguće je da je dvorska kapela izgrađena kao privatna kapelica ili grobnica nekog plemića, možda čak i bana Borića, koji u 12. stoljeću drži mnoge posjede u tom dijelu Slavonije (Mihaljević, Horvat, Matković 2014) i ima odlične veze s ugarsko-hrvatskim kraljevskim dvorom. I konačno, zadnje, ali ne i najmanje važno jest da zapadnu prigradnju naše rotunde $u$ Ivandolu treba smatrati - Westwerkom, koji je osobito razvijen u ranijoj srednjovjekovnoj arhitekturi, a namijenjen je nazočnosti visokorangiranih osoba feudalnog društva. 
Zanimljivo da Westwerk nalazimo u nedalekom benediktinskom samostanu na crkvi 15. stoljeća u Bijeloj, što je inače prilična rijetkost u kontinentalnoj Hrvatskoj, tj. srednjovjekovnoj Slavoniji. Visoka kvaliteta izvedbe potvrđuje mogućnost da je rotundu kraj Ivandola gradio ban Borić. Tragom istraživanja rotundi, smatramo da požeški kraj ima iznimne uvjete za proučavanje tog tipa srednjovjekovne centralne sakralne arhitekture i zavređuje pokretanje interdisciplinarnog projekta istraživanja rotundi u kontinentalnoj Hrvatskoj.

\section{Literatura}

Barle, Janko (1903), Zagrebački arciđakonat, Zagreb, Pretiskano iz Katoličkog lista, Zagreb.

Bobovec, Ana (1989), Arheološka topografija područja grada Kutine, Zbornik Moslavine, IV, Kutina, 12-23.

Butorac, Josip (1934), Župe požeškog arciđakonata, 1332-1335, Bogoslovska smotra, 22/1 Zagreb, 81-90.

Butorac, Josip (1984), Popis župa Zagrebačke biskupije 1334-i 1501, Starine JAZU, 59/1984, Zagreb, 43-107.

Buturac, Josip (2004), Pisani spomenici Požege i okolice (1210.-1536.), Naklada Slap, Jastrebarsko.

Burmaz, Josip, Živković, Janko 2007, Elaborat Zaštitna arheološka istraživanja svetišta kapele Sv. Križa u Otruševcu, Investitor: grad Samobor, Zagreb.

Dobronić, Lelja (1979), Po starom Moravču, Povijesni muzej Hrvatske, Zagreb.

Dobronić, Lelja (1984), Viteški redovi. Templari i ivanovci u Hrvatskoj, Kršćanska sadašnjost, Zagreb.

Heller, Georg (1975), Comitatus Poseganensis, Munchen.

Homen, Zoran. (1998 ), Rezultati prve etape arheoloških istraživanja u Glogovnici kraj Križevaca, U: Vjesnik muzealaca i konzervatora Hrvatske, 3/4, Zagreb, 22-26.

Horvat, Anđela. (1956), Spomenici arhitekture i likovnih umjetnosti u Medimurju, Zagreb.

Horvat, Anđela (1961), Prilozi povjesno-umjetničkim problemima u nekoć templarskoj Glogovnici kraj Križevaca, Peristil: zbornik radova za povijest umjetnosti, Vol.4 No. 1, prosinac 1961. Zagreb, 29-44.

Horvat, Anđela (1975), Između gotike i baroka, Zagreb.

Horvat, Anđela (1985), Prilog tipološkoj klasifikaciji romaničkih crkava kontinentalne Hrvatske, Bulletin Razreda za likovne umjetnosti Jugoslavenske akademije znanosti i umjetnosti, JAZU, Zagreb. 
Horvat, Zorislav (1967.-68.), Topusko - pokušaj rekonstrukcije tlocrta, Peristil, Zagreb, 10.-11/1967.-68., 5-16.

Horvat, Zorislav (1979), Benediktinski samostan u Bijeloj, u: Peristil, 22, Zagreb, 55-61. Horvat, Zorislav (1999), Neke činjenice o cistercitskom samostanu i crkvi u Topuskom, Pril. Inst. arheol. Zagreb, 13.-14./1996.-1997., str. 121-134.

Horvat, Zorislav (2005), Križevci - crkva Sv. Križa, Cris, god. VII., br. 1/2005., str. 24-41.

Houška, Mladen (2015), Zelinske crkve i kapele, Muzej Sveti Ivan Zelina.

Goss, Vladimir Peter (2012), Registar položaja i spomenika ranije srednjovjekoune umjetnosti u medurječju Save i Drave, Zagreb.

Karbić, Marija (2005), Posjedi plemićkog roda Borića bana do sredine XIV. stoljeća, Scrinia Slavonica, vol. 5, 48-61.

Korunek, Marijana (2014), Utvrđivanje namjene građevine kružnog tlocrta u dvorištu župne crkve sv. Jakoba u Prelogu, Godišnjak zaštite spomenika kulture Hrvatske, vol. 36 (2012), 83-89.

Ljubić, Šime (1880), VHAD, Zagreb. I/1880., 39-42.

Marasović, Tomislav, Gvozdanović, Vladimir, Sekulić-Gvozdanović, Sena, Mohorovičić, Andro, 1978, Prilozi istraživanju starohrvatske arhitekture, Split.

Mihaljević, Marija, Horvat, Zorislav, Matković, Marina (2014), Elaborat arheoloških istraživanja lokaliteta Njive-Ivandol, arhiv Konzervatorskog odjela u Požegi.

Mihaljević, Marija, Horvat, Zorislav, Matković, Marina, (2015), Arheološka istraživanja lokaliteta "Njive“ kod Ivandola 2013./2014., Godišnjak zaštite spomenika kulture Hrvatske, br. 39/2015, Zagreb.

Miletić, Drago (1984), Medvedgrad, u:KaJ, 6: 65-92, Zagreb.

Miletić, Drago, Valjato-Fabris, Marija (1987), Kapela sv. Filipa i Jakova na Medvedgradu, Zagreb.

Miletić, Drago (2012), Plemićki gradovi kontinentalne Hrvatske, Zagreb.

Marković, Mirko (2002), Slavonija - povijest naselja i podrijetlo stanovništva.

Moačanin, Nenad (2003), Požega i Požeština u sklopu Osmanlijskog carstva (1537.-1691.), Naklada Slap, Jastrebarsko.

Nemcsics, Akos (2012), Contribution to the medieval building technology based on the reconstruction of a rounded church, Exarc Journal, Issue 2012/1, EXARC, http:/ / exarc.net/issue-2012-1/ea/contribution-medieval-building-technologybased-reconstruction-rounded-church (20.11.2015.), https://exarc.net/issue-2012-1/ ea/contribution-medieval-building-technology-based-reconstruction-rounded-church (1.10.2018.). 
Petricioli, Ivo (1961), Rotunda u Malom Ižu, u: Peristil, 4:5, Zagreb.

Peškan, Ivana, Pascuttini-Juraga, Vesna (2009), Neka srednjovjekovna naselja i župe južnog varaždinskog podbrežja, Starohrvatska prosvjeta, III. serija - svezak 36/2009., Zagreb.

Radić, Mladen, Bojčić, Zvonimir (2004), Srednjovjekovni grad Ružica, Muzej Slavonije Osijek, Osijek. Rethy, Läszlö (1958), Corpus Nummorum Hungariae, Graz.

Smičiklas, Tadija (1905), Codex Diplomaticus Regni Croatiae, Dalmatiae et Slavoniae/Diplomatički zbornik Kraljevine Hrvatske, Dalmacije i Slavonije, Jugoslavenska akademija znanosti i umjetnosti, sv. III, Zagreb.

Sršan, Stjepan (2000), Naselja u istočnoj Hrvatskoj krajem 17. i početkom 18. stoljeća, Državni arhiv u Osijeku, Osijek.

Szabó, Gjuro (1908/1909), Lijesnica. Historijsko-geografska studija, Vjesnik hrvatskog arheološkog društva X, Zagreb, 40-46.

Szabó, Gjuro, (1917), Spomenici prošlosti u Srijemu, Savremenik, VI, Zagreb, separat.

Szabó, Gjuro (1929), Spomenici starije srednjovjekovne arhitekture u Hrvatskoj i Slavoniji, u: Zbornik naučnih radova rerdi Sišiću, Zagreb, 549-553.

Szilágyi, András (2009), A Kárpát-medence Árpád-kori rotundái és centratrális templomai, Budimpešta.

Tkalčić, Ivan Krstitelj (1874), Monumenta histórica episcopatus Zagrabiensis, I. i II. dio, Zagreb.

Tkalčić, Ivan Krstitelj (1887), Obnova i blagoslov župne crkve Sv. Križa u Križevcima, u: Katolički list, 38/1887, 20. rujna, Zagreb, 297-300.

Tkalčec, Tatjana (2013), Arheološka istraživanja lokaliteta Crkvari - crkva sv. Lovre 2012. godine, Annales Instituti Archaeologici IX, str. 20-25.

Unger, Emil (1997), Magyar Eremhatärozö I. Kötet (1000-1540), Budapest.

Vukičević-Samaržija, Diana (1986), Sakralna gotička arhitektura u Slavoniji, Zagreb.

Vukičević-Samaržija, Diana (1993), Gotičke crkve Hrvatskog zagorja, Institut za povijest umjetnosti, Zagreb.

Vukičević-Samaržija, Diana (2004), Umjetnička svjedočanstva srednjeg vijeka, u: Kulturna baština Požege i požeštine, Spin vallis, Požega, str. 164-181.

Uzelac, Zlatko (1984), Srednjovjekovna crkvica u Orljavcu, u: Požeški list, 22. III. 1984., Požega.

UNGARN - Bildhandbuch der Kunstdenkmaler, 1981, urednik: Istvan Genton, Beč.

Umelecke pamatky Čech (1980), III. dio: P/Š, Redakcija: Emanuel Poche, strana 285.

Zadnikar, Marijan (1982), Romanika v Sloveniji, Državna založba Slovenije, Ljubljana. 


\section{The Archaeological Research of the Njive-Ivandol Locality as a Tribute to the Study of the Mediaeval Period in the Požega Valley}

\section{Summary}

The paper presents the results of the research of the rotunda made of dressed stone, which was discovered in Njive-Ivandol, a mediaeval locality in the Požega County dated back to the Romanesque and the Gothic periods. It is presumed that the location of the rotunda was the former mediaeval estate of Odolja, which belonged to the grandson of ViceRoy Borić, whereas in the $13^{\text {th }}$ century, it was a property of the Knights Templar. The paper furthermore offers a survey of other rotundas in Croatia, as well as several examples from Europe, comparing thereby the frequency of the erection of this type of sacral buildings in the territory of Croatia in the time span including the High and the Late Middle Ages.

Keywords: rotunda; Middle Ages; dressed stone; Vice-Roy Borić; Odolja.

Dr. sc. Marija Mihaljević

Gradski muzej Nova Gradiška

Trg kralja Tomislava 7, 35400 Nova Gradiška

marija.mihaljevic111@gmail.com

Marina Matković, mag. archeol.

Ulica hrvatskog proljeća 47, Ribnica, 10410 Velika Gorica

Zorislav Horvat, dipl. ing. arh.

Zagrebačka 17, 10340 Vrbovec 